\title{
Substitution Between Individual and Source Country Characteristics: Social Capital, Culture, and US Labor Market Outcomes Among Immigrant Women
}

\author{
Francine D. Blau \\ Lawrence M. Kahn
}

CESIFO WORKING PAPER NO. 5306

CATEGORY 4: LABOUR MARKETS

APRIL 2015

An electronic version of the paper may be downloaded

- from the SSRN website:

- from the RePEc website:

- from the CESifo website: wWw.SSRN.com

www.RePEc.org

www.CESifo-group.org/wp 


\title{
Substitution Between Individual and Source Country Characteristics: Social Capital, Culture, and US Labor Market Outcomes Among Immigrant Women
}

\begin{abstract}
Using the New Immigrant Survey, we investigate the impact of immigrant women's own labor supply prior to migrating and female labor supply in their source country on their labor supply and wages in the US. Women migrating from higher female labor supply countries work more in the US. Most of this effect remains after controlling for the women's own labor supply prior to migrating, which itself also strongly positively affects US labor supply. We further find a significantly negative interaction between pre-migration labor supply and source country female labor supply. We obtain similar effects on hourly earnings among the employed.
\end{abstract}

JEL-Code: J160, J220, J240, J610.

Keywords: gender, immigration, labor supply, human capital.

Francine D. Blau

Labor Economics

Cornell University

USA - 14853 Ithaca NY

fdb4@cornell.edu
Lawrence M. Kahn

Labor Economics

Cornell University

USA - 14853 Ithaca NY

LMK12@cornell.edu

May 2011 - Revised June 2014

We are grateful for the helpful comments of Isaac Erlich, Peter Nijkamp, Stephen Trejo, two anonymous referees and participants at the IZA/Center of Human Capital Workshop on Migration and Human Capital, Bonn, May 2013; the ESOP Workshop on Gender and Households, University of Oslo, May 2011; the Society of Labor Economics Meetings, Chicago, May 2012; the Ninth Chinese Women Economists International Workshop on Empirical Research Using Micro Data, Beijing, June 2012; the 27th National Conference of Labour Economics (AIEL), Caserta (Italy), September 2012; and the Labor Seminar at Renmin University, Beijing, June 2012. We thank Peter Brummund for excellent research assistance and Cornell University for financial support. 


\section{Introduction}

In recent decades, the share of the US population that is foreign-born has risen from $4.8 \%$ in 1970 to 12.2\% in 2009 (US Bureau of the Census web site: http://www.census.gov ). Perhaps more dramatically, there has been a substantial shift in the source countries of immigrants: in 1970, 70.4\% of the foreign-born population came from Europe or North America, while, by 2009, 81.1\% were from Asia or Latin America (US Bureau of the Census web site: http://www.census.gov ). As the share of US residents who were born abroad rises and as the regions from which immigrants arrive shift toward areas with different cultures and traditions from the largely European origins of the US-born population, economists are paying increasing attention to issues of culture and assimilation. Recent research has shown that immigrants increasingly come from countries that have a more traditional division of labor by gender than the United States (Blau, Kahn and Papps 2011). Moreover, several studies have found a positive correlation between indicators of female labor force participation in an immigrant or second generation woman's source country and her labor supply behavior in the United States (Antecol 2000; Fernández and Fogli 2009; Blau, Kahn and Papps 2011; Blau, Kahn, Liu, and Papps 2013). Such findings are suggestive of cultural influences on female labor force behavior, particularly since the source-country effects on immigrants persist with long duration in the United States (Blau, Kahn and Papps 2011) and influence the labor supply behavior of second and higher generation women (Fernández and Fogli 2009; Blau, Kahn, Liu, and Papps 2013, Antecol 2000).

As suggested above, these source country effects may be seen as reflecting the impact of culture, which Fernández and Fogli (2009) define as: "systematic differences in preferences and beliefs across either socially or geographically differentiated groups” (p. 147). Such effects may, however, also reflect social capital, that is social interactions or community-level characteristics that enhance skills or productivity and hence wages. Social capital can, for instance, take the form of role models, expectations, behavioral norms, and interpersonal networks (see, e.g., Dasgupta 2008; Borjas 1992; Coleman 1988; and Wilson 1987). While the mechanisms of transmission of culture and social capital may overlap, the crucial distinction between the two is that culture operates mainly through preferences and beliefs whereas social capital is expected to impact productivity and wages. Thus, a reasonable test of the role of culture vs. social capital would examine the extent to which the impact of source country female supply on immigrant women's participation is due to its effect on wages and the extent to which it cannot be accounted for by wages. We acknowledge this distinction between culture and social capital is not watertight. For example, a preference for market work could also have the consequence of increasing productivity through its effect on the amount of work experience accumulated. And, conversely, higher wages may induce greater work experience, which might itself affect one's attitudes toward and preferences for work. Nonetheless, examining the role of wages in explaining the source country labor supply effect is likely to be instructive. ${ }^{1}$

Using a rich new data set, the New Immigrant Survey (NIS), we study the effects on immigrant women's current employment and wages in the United States of both their own premigration labor supply and the average female labor supply in their country of origin. An innovative feature of our work is that, because we are able to observe women's employment before they migrated, we are able to separate the effects of these two factors. This enables us to

\footnotetext{
${ }^{1}$ Fernández and Fogli (2009) also make the assumption that social capital can be correlated with an impact on wages. As discussed below, in contrast to our findings for immigrant women, they do not find an effect of source country female labor supply on wages of second generation women.
} 
present a much more detailed picture of the impact of culture and social capital on immigrant labor market outcomes than previous literature has done. ${ }^{2}$ If, as is likely, women from higher female labor supply countries have more work experience, then the observed effect of source country average female labor supply may be due, at least in part, to the relatively high levels of job-related human capital that they have accumulated before migration. An examination of the relationship between source country female activity rates and immigrant women's US labor supply, controlling for pre-migration labor supply, thus provides a sharper test of whether broader values and skills beyond those directly tied to their own employment have been transmitted to such women. In other words, such a test would provide evidence on the effect of broader culture or social capital in the relationship between source country participation rates and the US labor market behavior of immigrant women. Our examination of the impact of the source country variables on wages as well as employment also provides suggestive evidence on the role of culture versus social capital since the latter is expected to be more strongly tied to productivity and hence to wages.

An additional phenomenon we are able to study is whether culture and social capital, as indicated by the labor force activity of women in the source country, and immigrant women's own pre-migration work experience act as substitutes or complements in affecting employment and wages in the US labor market. Both possibilities are plausible. For example, growing up in a country where women typically work may provide women with role models for how to be an employee and affect their aspirations and preferences for market work. Such exposure could substitute for the woman's own work experience since even women who did not work before migrating may have acquired some work orientation or job-related skills by observing friends or relatives in their source country. Alternatively, culture and social capital may complement actual work experience if, for example, having role models in one's source country enhances the quality of one's work experience there or its impact on one's work orientation. Prior research on immigrant labor market outcomes has not examined these issues. Moreover, by investigating this relationship for both employment and wages, we will gain insight on the role of culture compared to social capital in producing the effect.

Evidence on the effects of source country and women's own pre-migration work experience could also yield important information about the likely impact of immigration policies on the labor force behavior of the women who migrate. For example, US policies regarding diversity visas have a direct effect on the distribution of countries from which immigrants arrive and therefore the cultural backgrounds of those migrants who are granted visas. $^{3}$ Employment visas, on the other hand, are likely to be selective of those with previous work experience; thus, policies regarding the number of such visas may directly affect the prior work experience of immigrants as well as indirectly affecting the types of source countries they migrate from. Since immigration policies may have differing effects on the distribution of source countries and the pre-migration labor supply of migrant women, it is important to have information on the impact of both source country characteristics and actual pre-migration behavior on immigrant women's US labor supply.

Similar to previous work (Antecol 2000; Blau, Kahn and Papps 2011), we find that women who migrate from countries with relatively high levels of female labor supply work more

\footnotetext{
2 As discussed in more detail below, this feature of our design is similar conceptually to Fernández and Fogli's (2006) analysis of the fertility of US-born women from different ethnic backgrounds. We describe our data in detail below.

3 The US Diversity Immigrant Visa Program creates 50,000 diversity visas each year, which are given by lottery to those from countries with low immigration rates to the United States. See http://travel.state.gov/visa/immigrants/types/types_1322.html .
} 
in the United States. Of particular interest is that, using the NIS, we are able to show that most of this effect remains when we further control for each woman's own labor supply prior to migrating, and, moreover, that immigrant women's pre-migration labor supply also strongly positively affects their labor supply in the United States. Finally, we find a significantly negative interaction between pre-migration labor supply and source country female labor supply. We obtain broadly similar results analyzing the determinants of wages (hourly earnings) among immigrant women who are employed in the United States, although the effects are not always significant. We also show that, given plausible values of labor supply elasticities, most of the impact of source country female labor supply is not due to its impact on wages, suggesting that culture rather than social capital is the primary factor accounting for the source country effect on labor supply. The negative interaction effects between pre-migration work experience and source country female labor supply on immigrant women's US work hours and wages suggest that culture and social capital can substitute for individual job-related human capital and work orientation in affecting preparedness and preferences for work in the United States.

\section{Relationship to Previous Literature and Contribution of the Study}

Our analysis builds on some recent papers that have studied the impact of source country characteristics on the labor supply of immigrant women. For example, Antecol (2000) found, using the 1990 Census, that source country female labor force participation rates were positively correlated with the US labor force participation of immigrant women, even controlling for human capital characteristics. Blau, Kahn and Papps (2011) further elucidated the nature of this relationship by examining the impact of source country characteristics on immigrant women's labor supply assimilation profiles - the relationship between time in the United States and labor supply. They found strong positive assimilation for all groups but that migrating from a country with higher female labor force participation permanently raised immigrant women's labor supply profile in the United States. Those who came from high female labor supply countries eventually assimilated fully to native labor supply levels, while there was a persistent $10-12 \%$ shortfall relative to comparable natives among those who migrated from a low female labor supply country. In addition, Blau's (1992) study, which found a positive effect of source country fertility rates on immigrant women's fertility, also suggests an impact of gender roles in source countries on the behavior of immigrant women in the United States.

As noted above, several studies have found an impact of source country characteristics on the behavior of US-born women descended from immigrants (Antecol 2000; Fernández and Fogli 2009; Blau, Kahn, Liu, and Papps 2013). Of particular relevance to this study, Fernández and Fogli (2006) employ a research design that is conceptually similar to ours to examine the impact of culture on the fertility of US-born women from different (self-reported) ethnic backgrounds. Using General Social Survey data from 1977-1987, they control for both the fertility of the respondent's own parents (i.e., her number of siblings) and the 1950 fertility rate in her country of ancestry. Both variables positively affected current fertility and, since the impact of the source country fertility level was still positive even controlling for the number of siblings, the results suggest an impact of culture beyond the behavior of one's own family.

While prior results relating immigrant women's US labor supply to female labor force participation in their source countries suggest an impact of culture or social capital, they do not provide much insight into the possible mechanisms behind this relationship, in particular the role of prior work experience in the country of origin. The data sets generally used to analyze immigrant behavior in the United States - the Census, the American Community Survey (ACS), 
and, since 1994, the Current Population Survey (CPS)—contain information on immigrants’ source countries and their behavior in the United States, but not on immigrants' work behavior prior to migrating. National origin country data sources, from which labor force behavior in source countries may be calculated, do not of course break out the behavior of residents from that of future migrants to the United States. Thus, in this paper, we study these issues using a relatively new data set, the New Immigrant Survey (NIS), which contains information not only on immigrants' source countries and labor supply behavior in the United States, but also on their labor supply and the schooling they received before migrating. The NIS allows us to disentangle the effects of the migrant's own past behavior from the impact of broader culture and social capital represented by source country characteristics. Because the NIS contains information on when the respondent left the source country, we can assign source country characteristics as of the date of migration, as in Blau, Kahn, and Papps (2011). Moreover, unlike the Census, ACS, or CPS, the NIS contains detailed information on visa type, allowing for a more extensive set of controls in studying immigrants' labor market behavior and outcomes. In addition to allowing for a more detailed study of the role of culture or social capital than is possible in other data sources, as mentioned earlier, the NIS data also allow us to test whether broader environmental factors (proxied by source country female participation rates) and pre-migration work experience act as substitutes or complements in the formation of immigrant women's labor market preferences and skills.

\section{Data and Descriptive Patterns}

Our basic data source, the NIS, is a nationally-representative survey of 8573 adult immigrants who received admission to permanent legal residence in the United States in 2003 (Jasso, Massey, Rosenzweig and Smith forthcoming). ${ }^{4}$ The respondents were interviewed during 2003 or 2004 with about 2/3 of the sample surveyed in the earlier year. Some had just arrived in the United States with permanent residence visas already issued, while others were already in the United States, either under temporary visas or illegally. ${ }^{5}$ Although the NIS is not representative of all immigrants (because presumably some never become legalized or some temporary migrants never adjust to permanent status), it does represent a random sample of those obtaining permanent legal status in a given year. ${ }^{6}$ The NIS contains information on the respondent's country of birth and when the immigrant left his/her source country. We use this information to match source country characteristics from a time-series cross-section data base we constructed, as described in more detail below and in the Appendix. A key component of our design is that we are able to measure source country variables at the time the individual left the source country. This is a potentially important feature of our analysis, since we would like to know the kinds of norms and values the respondent grew up with.

Our sample is restricted to individuals who migrated as adults (age 18 and over) and were currently no older than 65 . Focusing on adult immigrants is appropriate because we want to study the effects of the source country environment on US behavior, and those who migrated as children may be very Americanized by the time they reach adulthood. Moreover, since we wish

\footnotetext{
4 A small fraction (about 0.5\%) were admitted during 2002. For additional information on the NIS, see: http://nis.princeton.edu/ .

5 Those on temporary visas include some with very high levels of human capital (such as university students or technical workers) as well those with lower human capital levels (such as agricultural workers).

${ }^{6}$ Below, we compare the NIS sample to samples of recent immigrants from the Census and ACS; the Census and ACS samples are more representative of recent immigrants (including both permanent and temporary, as well as both legal and unauthorized, immigrants).
} 
to examine the role of pre-migration labor market experience, we need a sample of individuals for whom this is a realistic possibility. (Results were very similar when we restricted the sample to those who migrated at age 25 or later.) We also exclude the small number of newly legalized immigrants who were not currently living in the United States (about 1.2\% of the sample), although the results were virtually identical including them. The NIS supplied a set of sampling weights, which we use in all of our analyses, thereby assuring that we have a representative sample of newly legalized immigrants.

Table 1 shows descriptive information for the NIS sample for men and women overall as well as separately for three major source regions: South and East Asia; Latin America and the Caribbean; and Europe and Central Asia. Panel A gives means for selected individual characteristics from the NIS, which, as noted, contains information not available in other data bases on immigrants. Panel B shows means for the source country characteristics that we have merged into the NIS data. Appendix Table A1 contains the list and sample sizes corresponding to the 27 source countries or, in a few instances, regions available from the NIS. The means of the source country characteristics in Table 1 are implicitly weighted by the (weighted) number of immigrants from each country.

Several conclusions about gender and employment before and after immigration emerge from Table 1. First, overall, immigration seems selective of women with high relative work propensities. This can be seen by comparing the gender ratio for the average incidence of premigration employment among immigrants shown in Panel A to the gender ratio for activity rates in the source country shown in Panel B. ${ }^{7}$ Table 1 shows that before migration, women were $78 \%$ as likely as men to have worked for pay (i.e., $0.532 / 0.686 \approx 0.78$ ), while the average female/male activity rate ratio in migrants' source countries at the time they migrated was only 59-60\% (see Panel B). In addition to selection on unmeasured characteristics, the higher female/male premigration employment ratio in the NIS compared to the source country average may also be due to the age or education composition of immigrants or to temporarily high labor supply among immigrant women earning money before leaving their source country to help finance their (and their family’s) migration.

Second, in terms of the labor supply behavior of the specific women who do migrate, the results in Panel A suggest that migration widens the gender gap in employment or work hours, where employment or labor force participation in the United States refers to behavior as of the survey date, and hours worked in the United States refers to work during the past year. For example, $53.2 \%$ of women worked before migrating, compared to $46.8 \%$ after coming to the United States (a 6.4 percentage point decline, or about 12 percent of the pre-migration mean); for men, the share working rose from $68.6 \%$ before migration to $73.6 \%$ in the United States $(7.3$ percent relative to the mean). While average work hours (including those not working) fell for both men and women, they fell much more for women (306 hours, or 29.4\%) than for men (114 hours, or 7.5\%). ${ }^{8}$ Several interpretations of these changes in labor supply are possible. On the one hand, perhaps women are returning to their intended labor supply levels, which may have been temporarily inflated pre-migration in an attempt to help finance their move. Alternatively, it is possible that women's early labor supply in the US is temporarily reduced due to their having greater difficulty than men in locating employment; this would particularly be the case if they were married women and "tied movers" (Mincer 1978 and Cooke, Boyle, and Couch 2009). The disruption of moving may also result in a disproportionately high level of family

\footnotetext{
7 While the activity rates include unemployment, the NIS does not contain information on pre-migration unemployment.

${ }^{8}$ Using the NIS data, Akresh (2008) found that women experience larger post-migration reductions in occupational prestige than men, a pattern that is similar to the labor supply comparisons we obtain here.
} 
responsibilities for women under a traditional division of labor. Gender differences in visa types could also contribute to this result. The NIS data show that family visas were by far the most common method of attaining legal permanent resident status for both sexes, but were more common among women than men. Fully $62.5 \%$ of women compared to $47.6 \%$ of men had such visas. Not surprisingly, the reverse was true for employment visas, which were somewhat more common for men (14.5\%) than women (10.1\%). Finally, men were better educated than women on average (their pre-migration education levels were .7 years higher) and their average hourly earnings in the United States (based on earnings and work hours during the past year) were about $.20 \log$ points higher.

In addition to these results for all immigrants, Table 1 shows some interesting patterns among the three major source regions represented in the NIS. Pre-migration labor supply among women (see Panel A) is ranked similarly to the average source country female/male activity rate ratio (see Panel B), with considerably lower average hours worked for women from Latin America and the Caribbean than for women from Europe and Central Asia and South and East Asia. And, while women's labor supply after migration hardly changed for those migrating from Latin America and the Caribbean region, it fell sharply after migration for those from the other two regions. The gender gap in US labor supply was smaller both absolutely and relatively for those migrating from Europe and Central Asia than for those migrating from the other two regions, while the gender pay gap was smaller for those from Latin America and the Caribbean area than for those from the other two regions. Gender differences in the level of pre-migration schooling also differed by region. Men and women from Europe and Central Asia had about the same level of pre-migration schooling, while men's pre-migration schooling was somewhat higher than women's among those moving from Latin America and the Caribbean area and considerably higher than women's for those migrating from South and East Asia. There were also some differences by visa type across the regions. Legalization visas were especially common among those migrating from Latin America and the Caribbean, likely reflecting the relative ease of illegal border crossings, given their physical proximity to the United States, raising the stock of those potentially requesting such visas. ${ }^{9}$ There was a higher incidence of employment visas among those migrating from South and East Asia; this may reflect their longer distance of migration, a fixed cost that requires a larger labor market return to migration to offset (Chiswick 1978). ${ }^{10}$ The gender gap in employment visas was also particularly large for this group as well.

Looking at the means for other source country characteristics shown in Panel B, we see that, not surprisingly, the Europe and Central Asia region has higher levels of income, lower fertility, higher female activity rates, and higher schooling levels than the other two regions. In contrast, the Latin America and Caribbean region has relatively high fertility, low income, low education and low female supply. The international differences on these dimensions at the source-country level provide a source of variation among immigrants that we will use in our empirical analyses.

\footnotetext{
${ }^{9}$ The legalization category in the NIS includes those whose visa status was adjusted to a permanent visa under provisions of the Nicaraguan Adjustment and Central American Relief Act (NACARA) or the Immigration Reform and Control Act (IRCA). In some of these cases, a previous order of deportation was canceled, although the NIS doesn't separately identify such instances.

10 The high incidence of employment visas from South and East Asia could also reflect high education levels; however, we note that education levels are even higher for immigrants from Europe and Central Asia even though employment visas are less common among immigrants from there than from South and East Asia.
} 
Table 1: Means for the Full Sample and by Birth Region, Adult Immigrants, NIS

\begin{tabular}{|c|c|c|c|c|c|c|c|c|}
\hline & \multirow{2}{*}{\multicolumn{2}{|c|}{ Full Sample }} & \multicolumn{6}{|c|}{ Latin America and } \\
\hline & & & \multicolumn{2}{|c|}{ South and East Asia } & \multicolumn{2}{|c|}{ Caribbean } & \multicolumn{2}{|c|}{ Europe and Central Asia } \\
\hline & Women & Men & Women & Men & Women & Men & Women & Men \\
\hline \multicolumn{9}{|l|}{ A. Personal Characteristics } \\
\hline Annual Work Hours in US & 735.486 & 1399.277 & 618.773 & 1214.536 & 815.425 & 1520.228 & 888.304 & 1470.217 \\
\hline Currently In Labor Force in US & 0.594 & 0.907 & 0.588 & 0.879 & 0.585 & 0.932 & 0.667 & 0.906 \\
\hline Currently in School in US & 0.088 & 0.081 & 0.072 & 0.060 & 0.080 & 0.067 & 0.128 & 0.071 \\
\hline Currently Employed & 0.407 & 0.724 & 0.350 & 0.636 & 0.434 & 0.794 & 0.513 & 0.747 \\
\hline Annual Work Hours Before Migrating & 1041.368 & 1512.841 & 1128.387 & 1532.505 & 860.416 & 1345.353 & 1368.044 & 1812.899 \\
\hline Worked Before Migrating & 0.532 & 0.686 & 0.531 & 0.674 & 0.471 & 0.625 & 0.721 & 0.809 \\
\hline Log hourly earnings in US & 2.290 & 2.494 & 2.334 & 2.632 & 2.155 & 2.353 & 2.425 & 2.724 \\
\hline Married, Spouse Present & 0.785 & 0.780 & 0.859 & 0.829 & 0.717 & 0.756 & 0.820 & 0.830 \\
\hline Number of Own Children & 1.757 & 1.531 & 1.417 & 1.549 & 2.330 & 1.860 & 1.133 & 1.141 \\
\hline Age & 37.932 & 38.166 & 38.195 & 40.466 & 38.995 & 37.752 & 36.331 & 38.144 \\
\hline Years of Schooling Before Migrating & 11.902 & 12.601 & 12.644 & 13.802 & 10.144 & 10.464 & 14.130 & 14.084 \\
\hline Years of Schooling in US & 0.381 & 0.579 & 0.430 & 0.603 & 0.276 & 0.472 & 0.535 & 0.605 \\
\hline Years Since Migration & 4.686 & 5.964 & 2.860 & 4.055 & 6.794 & 8.395 & 3.792 & 4.950 \\
\hline Other Visa & 0.086 & 0.095 & 0.076 & 0.133 & 0.134 & 0.118 & 0.020 & 0.037 \\
\hline Family Visa & 0.625 & 0.476 & 0.666 & 0.448 & 0.655 & 0.572 & 0.475 & 0.368 \\
\hline Employment Visa & 0.101 & 0.145 & 0.203 & 0.331 & 0.026 & 0.040 & 0.081 & 0.124 \\
\hline Diversity Visa & 0.073 & 0.120 & 0.030 & 0.046 & 0.007 & 0.015 & 0.256 & 0.285 \\
\hline Refugee Visa & 0.061 & 0.084 & 0.025 & 0.034 & 0.040 & 0.063 & 0.165 & 0.180 \\
\hline Legalization Visa & 0.055 & 0.080 & 0.000 & 0.008 & 0.138 & 0.193 & 0.002 & 0.005 \\
\hline Born in South/East Asia & 0.347 & 0.282 & 1.000 & 1.000 & 0.000 & 0.000 & 0.000 & 0.000 \\
\hline Born in Latin America/Caribbean & 0.393 & 0.389 & 0.000 & 0.000 & 1.000 & 1.000 & 0.000 & 0.000 \\
\hline Born in Sub-Saharan Africa & 0.062 & 0.087 & 0.000 & 0.000 & 0.000 & 0.000 & 0.000 & 0.000 \\
\hline Born in Europe/Central Asia & 0.137 & 0.171 & 0.000 & 0.000 & 0.000 & 0.000 & 1.000 & 1.000 \\
\hline Hispanic & 0.344 & 0.328 & 0.012 & 0.016 & 0.857 & 0.824 & 0.008 & 0.007 \\
\hline Asian, Nonhispanic & 0.340 & 0.277 & 0.946 & 0.940 & 0.008 & 0.009 & 0.017 & 0.013 \\
\hline Black, Nonhispanic & 0.104 & 0.140 & 0.005 & 0.002 & 0.110 & 0.144 & 0.003 & 0.007 \\
\hline Other, Nonhispanic & 0.011 & 0.011 & 0.019 & 0.031 & 0.008 & 0.004 & 0.000 & 0.002 \\
\hline White, Nonhispanic & 0.202 & 0.244 & 0.017 & 0.011 & 0.018 & 0.019 & 0.973 & 0.971 \\
\hline
\end{tabular}


Table 1 (cont'd): Means for the Full Sample and by Birth Region, Adult Immigrants, NIS

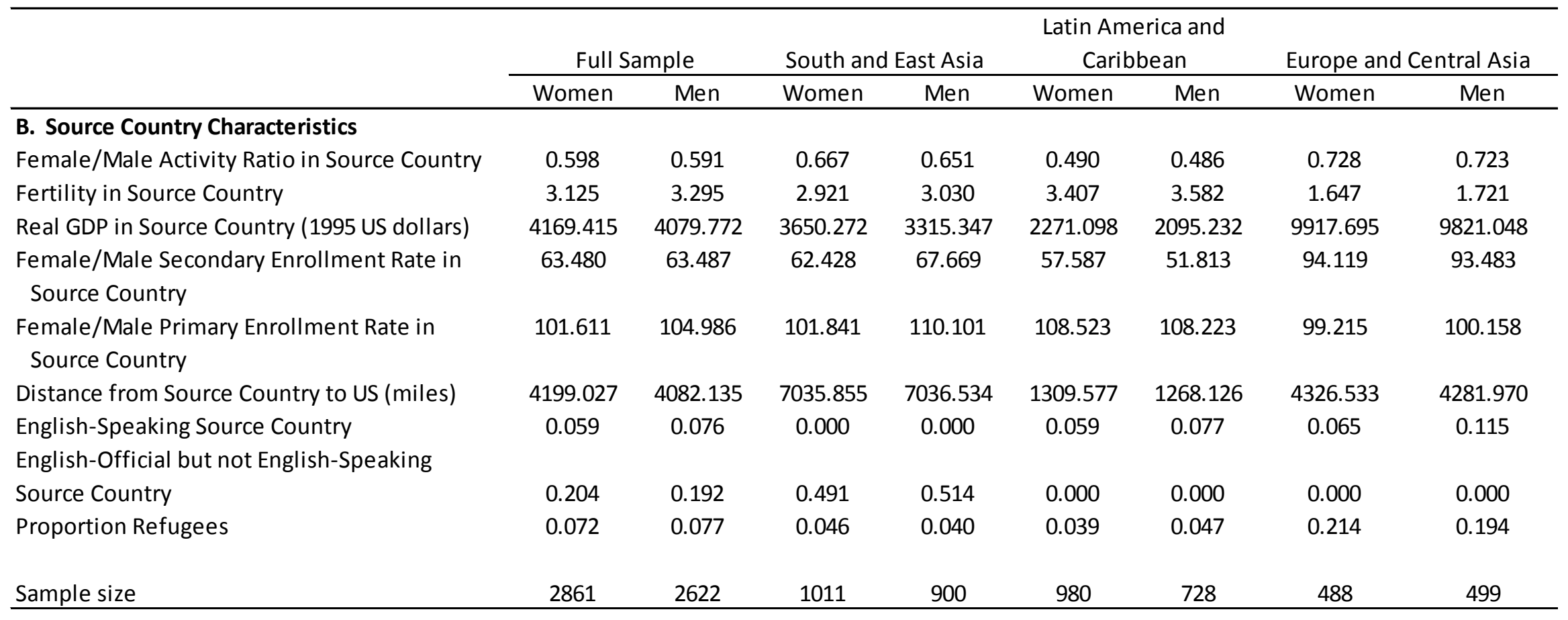


Since the NIS sample includes only legal immigrants who have been issued permanent residence visas, it may not be representative of all immigrants. A large share of immigrants is believed to be unauthorized and, in any given year, most immigrant visas issued are temporary rather than permanent. For example, the Department of Homeland Security estimated that as of January 2006, 39.6\% of the US foreign-born population was unauthorized (Hoefer, Rytina and Campbell 2007, p. 3). And, Department of Homeland Security (2012) data show that the number of temporary worker, family or student visas granted in 2002 was about double the number of permanent visas issued, and this gap grew during the decade (pp. 5, 63 and 65). To shed light on the question of whether the NIS is representative of the US population of recent immigrants, it is instructive to compare the NIS data to US Census and ACS data, which contain information on both legal and unauthorized immigrants, as well as those on temporary or permanent visas, albeit in unknown proportions. ${ }^{11}$ Appendix Table A2 shows information from the 2000 US Census and 2005 ACS on similar variables (when available) for foreign-born individuals who arrived in the United States in the last 5 years (about 69\% of the NIS sample arrived during the previous 5 years), and the corresponding figures from the NIS are included for comparison purposes. In addition, to more closely match our NIS sample, the ACS and Census respondents are restricted to those who migrated at age 18 or later and are no older than 65 years of age. ${ }^{12}$

Several interesting contrasts and similarities emerge from the comparison between the NIS and the Census Bureau data sets. First, the NIS sample is older than the immigrant respondents in the Census or the ACS - mean age was 38 for the NIS compared to 32-34 for the Census and ACS. This difference is consistent with the inclusion of unauthorized immigrants and those on temporary visas in the Census and ACS samples, since it is likely that it takes a significant amount of time to obtain permanent resident status.

Second, the NIS respondents are more highly educated than those in the Census or ACS: in the NIS, total years of schooling (the sum of years of schooling obtained before migrating and in the US) average 13.2 for men and 12.3 for women, compared to an average of 11.8-12.3 in the Census and ACS. ${ }^{13}$ It is likely that the sample of NIS respondents contains a disproportionate share of those with work qualifications and therefore higher schooling levels. Moreover, there is a gender gap in education favoring men in the NIS, while, in the Census and ACS, women have slightly higher levels of schooling. This pattern is consistent with those entering with permanent work visas being disproportionately male (as we have seen is the case) and unauthorized immigrants or those on temporary visas being disproportionately comprised of less educated men. The possibility that unauthorized immigrants are included in the Census and ACS is also supported by the pattern showing larger shares of immigrants from Latin America and the Caribbean area in the Census and ACS than in the NIS. In addition, taking into account sampling weights, the 2000 Census and 2005 ACS samples consist of 52.1-52.5\% men; in contrast the figure for the NIS is $42.5 \%$. Again, a higher level of authorized immigration among men is suggested.

Importantly, however, despite these differences in demography and education, the gender gaps in work behavior and wages are very similar in the NIS compared to the Census and ACS. In the NIS, men work an average of 1399 hours (including those with zero work hours),

\footnotetext{
${ }^{11}$ In addition, unauthorized immigrants may be underrepresented in these data sets.

${ }^{12}$ ACS or Census respondents who had an allocated value for birthplace are excluded, and data are weighted using the provided sampling weights.

${ }^{13}$ Because the Census and ACS code education in categories, we use Jaeger's (1997) suggested algorithm to convert these to years of schooling.
} 
compared to 1436-1634 in the Census and ACS; women in the NIS work 735 hours, compared to 764-826 hours in the Census and ACS. (Other measures of labor supply show also show comparable levels in the NIS and the Census data sets.) And, the gender pay gap is roughly 0.20 log points in the NIS, compared to 0.14-0.16 in the Census and ACS. ${ }^{14}$ Thus, overall, for the purposes of analyzing work behavior, the NIS seems fairly representative of all recent immigrants, despite its limitation to those with permanent resident status. ${ }^{15}$

\section{Empirical Procedures and Regression Results}

\section{A. Empirical Procedures}

We study the role of source country environment (culture and social capital) and women's pre-migration work experience for two dependent variables. First, we analyze their effects on immigrant women's labor supply, and second, we study their impact on wages among employed immigrant women. Together, the findings will allow us to infer the effects of source country environment on labor supply and human capital.

We analyze labor supply in the United States by estimating the following equation for immigrant i migrating from source country $\mathrm{c}$ at time t:

$$
\mathrm{H}_{\mathrm{ict}}=\mathrm{F}\left(\mathrm{X}_{\mathrm{i}}, \mathrm{Z}_{\mathrm{ct}}, \mathbf{u}_{\mathrm{i}}\right)
$$

where $\mathrm{H}$ is annual hours worked in the United States, including zeroes; $\mathrm{X}$ is a vector of personal characteristics; $\mathrm{Z}$ is a vector of source country characteristics measured at the time of migration; and $\mathrm{u}$ is a disturbance term. The sample is restricted to women who migrated at age 18 or over and were currently no more than 65 years old. We estimate (1) as a linear regression, although implementing a Tobit analysis to take account of the mass of points at zero hours led to very similar results. Standard errors were clustered at the source country level, allowing for a correlation across respondents from the same country regardless of the time of arrival.

Equation (1) is a reduced form of a structural labor supply model. The explanatory variables therefore can affect wage offers, which will influence desired work hours, as well as reflecting individuals' work propensities controlling for wage offers. ${ }^{16}$ Each of the variables in X and $\mathrm{Z}$ can therefore be interpreted as possibly affecting both routes through which individuals make labor supply decisions.

$\mathrm{X}$ includes current age; age squared; a dummy for married spouse present; years of schooling completed before migrating; ${ }^{17}$ years since migrating to the United States (ysm); ysm squared; a series of race/ethnicity dummy variables including: Hispanic, Asian Nonhispanic,

\footnotetext{
14 The NIS provides information on the respondent's rate of pay and the time unit upon which this is based (i.e., hourly, weekly, bi-weekly, monthly, or annually). Combined with information on weeks worked in the last year and usual work hours, we can compute an hourly earnings measure. The NIS also has information on labor income in the last year. However, since there are more missing values for this variable than for the rate of pay on one's job, we use the latter in our wage analyses. We compute average hourly earnings in the Census and ACS using annual wage and salary income divided by annual work hours for wage and salary workers.

${ }^{15}$ Of course, recent immigrants differ from the stock of immigrants. For example, in the 2005 ACS, recent immigrants (those who migrated in the last five years) are slightly more likely to have been born in the Latin America/Caribbean region than the stock of immigrants, and recently arrived immigrants have fewer work hours than those who have been in the United States for a longer period of time. However, as Blau, Kahn, and Papps (2011) show, differences across source countries in work hours among recent immigrants persist in the long run. Thus, the work behavior of recently arrived immigrants, such as those in the NIS, is likely to be informative about longer run trends.

${ }^{16}$ We use the term "wage offer" because some choose not to work even if they have wage offers.

${ }^{17}$ We do not include years of schooling in the US as an explanatory variable since, as a form of time allocation, it may be viewed as endogenous to the labor supply decision.
} 
Black Nonhispanic, and Other Nonwhite Nonhispanic; and annual work hours before migrating, including zeroes. $\mathrm{Z}$, the source country characteristics (measured at the time of arrival), include the female/male activity rate ratio; completed fertility; GDP in 1995 US dollars; gender-specific primary and secondary enrollment rates; distance to the United States; and dummies for Englishspeaking and for English-official but not English speaking countries. The construction of these variables is described in detail in the Appendix.

The personal characteristics variables are intended to measure preparedness for the US labor market, labor supply propensities including the value of home time and tastes for work, and job opportunities. Age, schooling, and race/ethnicity may be proxies for human capital, the quality of schooling, or discrimination. Labor supply before migration and marital status may reflect human capital as well, or labor supply propensity given human capital levels. While we expect older and more highly educated individuals to have higher wages (thus increasing their quantity of labor supply), we cannot say a priori what impact these variables have on tastes or propensities for work. The years since migration variable likely combines both true assimilation as well as cohort effects. Since the NIS consists of one cross-section, it is not possible to disentangle these employing Borjas' (1985) design usingf multiple cross-sections or Lubotsky's (2007) longitudinal data approach. Nonetheless, years since migration is a potentially important control, since, as noted earlier, about $31 \%$ of immigrants who obtained legal permanent resident status arrived more than five years before the NIS survey. ${ }^{18}$

Source country variables were selected to serve as indicators of the degree to which the source country has a traditional division of labor by gender, the extent of labor market preparedness of men and women from that country, and also to address possible issues of selective migration. Female relative labor supply and fertility rates in the source country are indicators of traditional gender roles in the country of origin which may, as previously discussed, influence US labor supply as indicators of culture or social capital. Our particular focus here is on source country relative labor supply. Note that the measure we employ is women's labor force participation (activity rate) relative to men's (female LFP/male LFP). This relative measure is appropriate in that it captures the gender division of labor explicitly. A further advantage is that it implicitly adjusts for any problems in measuring the labor force, particularly at different levels of economic development, at least to the extent that such problems affect men's and women's measured participation rates similarly. Income, education, and use of English are all likely to be related to preparedness for work in the US labor market. In addition, migration probably involves a disruption of work patterns due to housing and job search in the United States. Those who came a long distance may suffer the largest disruption, negatively affecting their labor supply on arrival in the United States. On the other hand, as noted, because of the fixed costs of migration, those who choose to come from a greater distance are likely to have higher labor market returns to migration than those coming from shorter distances, all else equal (Chiswick 1978). Therefore, distance could be either positively or negatively associated with labor supply in the United States.

Since we have controlled for actual work behavior and schooling before migrating, the source country variables can be interpreted as indicators of community-level effects on the US labor supply of immigrant women. Moreover, an important test we implement is to interact the respondent's pre-migration labor supply with the female relative activity rate. The sign of this

\footnotetext{
${ }^{18}$ We use the date on which one first entered the United States to calculate years since migration. However, in light of Redstone and Massey's (2004) research showing that multiple entries are common (possibly interrupting one's accumulation of U.S.-specific experience), we also used the years since the most recent entry into the United States as an alternative measure of host country living experience. The results for either measure were very similar, and, indeed, the two variables had a correlation coefficient of 0.91-0.93. This may not be surprising, since the NIS consists disproportionately of recently-arrived immigrants.
} 
interaction effect will provide evidence on the degree to which actual work experience prior to immigration and source country female labor supply act as substitutes or complements in affecting preparedness or desire for work in the United States.

As mentioned earlier, equation (1) should be seen as a reduced form. Focusing on our key explanatory variable, source country female relative activity rates may, as suggested above, enhance immigrant women's social capital and thus increase their productivity and wage offers. This will in turn affect their labor supply in the United States through movements along a given supply curve. In addition, even controlling for wage offers, source country culture can affect women's preferences for working in the United States, in effect shifting their labor supply function to the right. Below, we examine the determinants of immigrant women's wage offers in the United States and use these results to make inferences about the direct and indirect effects of source country female relative activity rates on immigrant women's labor supply. These results also enable us to estimate the relative importance of culture versus social capital in accounting for the estimated effect of source country relative female activity rates on immigrant women's US labor supply. To do so, we make the assumption that the effect of source country relative female activity rates on wages is due to social capital, whereas culture affects preferences given wages. And we do believe these are the predominant effects. However, we acknowledge that there may be some spillovers in each direction. Building productivity through social capital may affect work orientation, while preferences for employment can affect human capital through labor force exposure.

In addition to the basic model outlined above, we also estimate some supplementary specifications to test the robustness or sharpen our interpretation of the basic results. First, we estimate the basic models for men. Such analyses may be of interest in and of themselves and also provide a useful check on our interpretations. For example, suppose we find that source country female labor supply is positively related to immigrant women's labor supply in the United States. While this effect may be due to the impact of culture and social capital on genderrelated norms and productivity, it may also be due to unobserved factors correlated with overall preparedness for work and work orientation of both men and women from the source country. Obtaining similar results for men would support the latter interpretation; however, if such a variable only (or predominantly) affects women, then it likely does reflect gender-related factors.

Second, research on the assimilation of immigrants has acknowledged the potential problem of selective return migration. Specifically, in a sample of immigrants, we only observe those who have decided to stay, and their labor market experience may not be representative of the full population of individuals who have ever migrated. For example Lubotsky (2007) finds evidence that stayers are positively selected. The immigrants in the NIS sample are mostly recent arrivals, so the problem of selective return migration may be less severe than in the Census, ACS, or CPS, which contain many immigrants who have been in the United States for many years. Nonetheless, even recent immigrants may be planning return migration, and these plans, while possibly endogenous with respect to source country labor supply and past work behavior, could influence immigrant women's employment in the United States. We address the issue of the possible selection bias due to return migration by using available data on emigration rates by source country (see the Data Appendix). Specifically, we include the female 1980-1990 emigration rate for immigrant women from the respondent's source country in some supplementary labor supply models. Adding this variable at least partially controls for differences across respondents in their plans to emigrate. However, since these plans themselves are likely to be affected by the respondent's own work history, culture, and social capital, our basic models are estimated without including the emigration rate. 
Third, in some models we include controls for the type of visa the respondent has obtained in achieving permanent resident status, a variable not available in other data sources. These include family visas, employment visas, diversity visas, refugee visas and legalization visas (e.g., those given during amnesties to people who were previously unauthorized), with the omitted category being unspecified visa type. While visa type is likely endogenous with respect to skills and labor supply intentions, it may be useful to control for it in order to sharpen the interpretation of the underlying individual labor supply and source country characteristics variables.

Fourth, we additionally include dummies referring to the region in which the respondent was born and controls for the respondent's current religious tradition and frequency of attendance at religious services in some labor supply models. The regions include Africa, East and South Asia, Latin America, Europe-Central Asia, and North America-Oceania, with the latter group omitted. We also in some models include dummies for the individual source countries identified in the NIS with the largest numbers of immigrants: Mexico, China, India, El Salvador and the Philippines. While the NIS data are not fine enough to permit individual source country dummies for all of the source countries, by adding regional controls or these five country indicators in some models, we are able to sharpen the interpretation of the source country characteristics. Religious tradition takes on nine possible values, referring to: Catholic, Orthodox Christian, Protestant, Muslim, Jewish, Buddhist, Hindu, Other Religion including those reporting multiple religions, and No Religion (the omitted category). Frequency of attendance at religious services is indicated by a series of dummy variables including: 1) never; 2) at least once per week; and 3) less than once per week but at least monthly, with some attendance but less than monthly as the omitted category. Controlling for the respondent's religious affiliation and frequency of attendance at services allows us to study the possible mechanisms through which source country environment can affect work behavior in the United States.

Fifth, in some models we control for education acquired in the United States and number of children ever born, again likely endogenous variables whose inclusion may reveal information about the effects of the woman's past labor supply and source country characteristics. ${ }^{19}$ Further, we experimented with alternative forms of the dependent variable and found similar results to those reported here. Specifically, we estimated models with current employment or labor force participation as the dependent variable. The latter dependent variable may be an especially important indicator of labor supply, since some groups of immigrant women have very high unemployment rates (see Blau and Kahn 2007b for data on Mexicans). If jobs are hard to find, then using annual work hours or employment may not give a complete picture of women's labor supply, although even the labor force participation rate does not include discouraged workers. Nonetheless, the labor force participation indicator will include at least some of those who would like to work but cannot find a job.

Finally, we also estimated models stratifying by marital status or educational attainment. The effect of traditional gender norms may be more in evidence among married than among single women; moreover, by restricting some samples to married women, we are able to control for spouse characteristics. Within the sample of married women, we estimate some models where the husband and wife both migrated from the same country. We further restrict some samples to married women who were already married when they migrated. This is a group that is especially likely to consist of tied movers, for whom the migration decision may be less affected by individual selection issues than for the migration population as a whole. Stratifying

${ }^{19}$ One might argue that marital status is similarly endogenous, and we also estimate some models excluding marital status. 
by education implicitly allows for possible substitution or complementarity relationships among formal schooling, source country female labor supply, and pre-migration labor supply.

In addition to analyzing labor supply, as noted above, we also study the determinants of hourly earnings among immigrant women who were wage and salary workers. We are particularly interested in the impact of pre-migration labor supply and source country female labor supply on the labor market opportunities facing immigrant women, as indicated by wage offers. We use a sample of wage and salary workers who are not currently enrolled in school and a similar specification of explanatory variables to that in the labor supply models, augmented by years of schooling obtained in the United States. This specification allows us to compare the value of schooling obtained before and after migration. In estimating the wage equations, we need to confront the issue of sample selection, since, as Table 1 shows, only about $41 \%$ of immigrant women in the NIS are currently employed. To correct for selectivity bias, we perform a traditional selectivity bias correction (Heckman 1979). In addition to functional form, the model is identified by including number of children, a variable that is excluded from the second stage (log wage) equation, in the first stage (probability of having a wage observation). We note that, since less than half of the sample is employed, we cannot use median regression methods to account for selection bias, as in Neal and Johnson (1996), Neal (2004), and Blau and Kahn (2006).

\section{B. Basic Regression Results}

Table 2 contains regression results for the determinants of annual work hours in the United States for immigrant women. We show several specifications, as indicated in our previous discussion. The first column shows the simplest specification, with only individual characteristics included and excluding visa type. Work hours before migrating have a positive, highly significant effect on work hours in the United States. The coefficient is 0.101, implying that a woman who worked the average number of hours among those who were employed prior to migrating (approximately 2000) will work roughly 202 hours (or about 27\% of the immigrant unconditional mean work hours) more than a woman who did not work before migrating to the United States. Column 2 shows that this effect remains the same when we add source country characteristics other than the female relative activity rate.

Column 3 shows the reduced form effect of the female relative activity rate obtained by excluding the respondent's own work hours prior to migration. The effect is 982 hours and is highly statistically significant. To gauge the magnitude of this effect, we note that the $75^{\text {th }}$ percentile of the female relative activity rate in our sample is .7045 (roughly the level in SubSaharan Africa) and the $25^{\text {th }}$ percentile is .4726 (roughly the level in the Dominican Republic). ${ }^{20}$ The estimate in column 3 implies that an increase from the $25^{\text {th }}$ to the $75^{\text {th }}$ percentile in the female relative activity rate will raise women's work hours by 228 hours (31\% of the mean).

Columns 4-6 of Table 2 explore the interplay between source country environment (the female/male activity rate ratio) and actual pre-migration labor supply in affecting immigrant women's work behavior in the United States. First, column 4 shows that adding the respondent's pre-migration work hours to the model reduces the effect of the source country female/male activity rate ratio by about 99 hours to a still highly significant value of 883 . Thus about $90 \%$ (883/982) of the total effect of source country culture remains even after we control for the

20 These percentiles are based on individual observations (with sampling weights), which means that countries with a large number of observations, such as Mexico, will get greater weight in computing the percentiles. 
Table 2: Selected OLS Results for the Determinants of Annual Work Hours (including zeroes), Adult Immigrant Women

\begin{tabular}{|c|c|c|c|c|c|c|}
\hline & $(1)$ & $(2)$ & (3) & (4) & (5) & (6) \\
\hline \multirow[t]{2}{*}{ Annual Work Hours Before Migrating } & $0.101^{* *}$ & $0.104^{* *}$ & & $0.100 * *$ & $0.236 * *$ & $0.217^{* *}$ \\
\hline & $(0.015)$ & $(0.015)$ & & $(0.015)$ & $(0.052)$ & $(0.053)$ \\
\hline \multirow[t]{2}{*}{ Female/Male Activity Ratio in Source Country } & & & $982.301 * *$ & $883.039 * *$ & $1117.018^{* *}$ & * $917.687 * *$ \\
\hline & & & $(260.354)$ & $(253.166)$ & $(243.831)$ & $(219.276)$ \\
\hline Interaction: Annual Work Hours Before & & & & & $-0.222^{* *}$ & $-0.193 *$ \\
\hline \multicolumn{2}{|l|}{ Migrating x Female/Male Activity Ratio } & & & & $(0.071)$ & $(0.073)$ \\
\hline \multirow[t]{2}{*}{ Married, Spouse Present } & $-186.398 * *$ & ${ }^{*}-188.218^{* *}$ & -162.119* & $-172.546^{* *}$ & $-171.304 * *$ & $-167.548 * *$ \\
\hline & (51.906) & (59.113) & $(59.555)$ & $(57.509)$ & $(57.453)$ & $(57.915)$ \\
\hline \multirow[t]{2}{*}{ Years of Schooling Before Migrating } & $15.670 * *$ & $11.876^{*}$ & $17.365^{* *}$ & $12.179 *$ & $11.536^{*}$ & $11.662 *$ \\
\hline & (4.697) & (4.864) & $(4.738)$ & $(4.722)$ & (4.716) & (4.938) \\
\hline \multirow[t]{2}{*}{ Years Since Migration (YSM) } & $137.957^{* *}$ & $140.377^{* *}$ & $141.136^{* *}$ & $142.323 * *$ & $141.601^{* *}$ & $121.725^{* *}$ \\
\hline & (10.316) & (11.112) & $(10.070)$ & (10.725) & (10.593) & (9.438) \\
\hline \multirow[t]{2}{*}{ YSM squared (/100) } & $-366.620 * *$ & * $-364.177^{* *}$ & k $-364.149 * *$ & k $-371.043^{* *}$ & $-368.464 * *$ & $-304.644 * *$ \\
\hline & (42.991) & $(43.010)$ & (45.401) & (45.097) & (44.781) & (39.725) \\
\hline \multirow[t]{2}{*}{ Fertility in Source Country } & & -35.442 & 42.385 & 32.749 & 30.549 & 32.540 \\
\hline & & (47.452) & $(42.654)$ & (36.069) & (34.675) & (35.786) \\
\hline \multirow[t]{2}{*}{ Real GDP in Source Country (\$US/1000) } & & -1.915 & 2.873 & 3.346 & 2.447 & 3.673 \\
\hline & & $(8.085)$ & $(7.066)$ & $(6.584)$ & $(6.641)$ & $(5.708)$ \\
\hline Female Secondary Enrollment Rate in Source & & 2.098 & 2.952 & 2.182 & 2.047 & 2.144 \\
\hline \multicolumn{2}{|l|}{ Country } & $(2.330)$ & $(1.867)$ & $(1.617)$ & $(1.599)$ & $(1.473)$ \\
\hline \multirow{2}{*}{$\begin{array}{l}\text { Female Primary Enrollment Rate in Source } \\
\text { Country }\end{array}$} & & -2.236 & -2.028 & -2.144 & -2.222 & 1.165 \\
\hline & & $(2.122)$ & (2.077) & $(2.065)$ & (2.039) & (1.686) \\
\hline \multirow{2}{*}{$\begin{array}{l}\text { Distance from Source Country to US } \\
\text { (miles/1000) }\end{array}$} & & $-39.274^{*}$ & $-61.194 * *$ & $-63.299 * *$ & $-62.929 * *$ & $-41.812^{*}$ \\
\hline & & (18.346) & (19.905) & (18.597) & (18.245) & (17.494) \\
\hline \multirow[t]{2}{*}{ English-Speaking Source Country } & & 31.080 & -139.015 & -116.874 & -106.963 & -17.000 \\
\hline & & (154.822) & (142.473) & (136.711) & (134.463) & (114.442) \\
\hline \multirow{2}{*}{$\begin{array}{l}\text { English-Official but not English-Speaking } \\
\text { Source Country }\end{array}$} & & $276.826^{* *}$ & $380.203 * *$ & $404.700 * *$ & $395.647^{* *}$ & $321.082^{* *}$ \\
\hline & & $(92.393)$ & $(80.557)$ & $(82.262)$ & $(82.092)$ & $(66.290)$ \\
\hline \multirow[t]{2}{*}{ Family Visa } & & & & & & $193.079 *$ \\
\hline & & & & & & (72.409) \\
\hline \multirow[t]{2}{*}{ Employment Visa } & & & & & & $410.335^{* *}$ \\
\hline & & & & & & (134.603) \\
\hline \multirow[t]{2}{*}{ Diversity Visa } & & & & & & 153.012 \\
\hline & & & & & & (97.697) \\
\hline \multirow[t]{2}{*}{ Refugee Visa } & & & & & & $600.809 * *$ \\
\hline & & & & & & (89.049) \\
\hline \multicolumn{2}{|l|}{ Legalization Visa } & & & & & $538.123 * *$ \\
\hline $\mathrm{N}$ & 2861 & 2861 & 2861 & 2861 & 2861 & 2861 \\
\hline Adjusted R squared & 0.220 & 0.226 & 0.219 & 0.231 & 0.233 & 0.249 \\
\hline
\end{tabular}
$+p<0.10, * p<0.05, * * p<0.01$

Note: Sample includes those who migrated at age 18 or later and who are currently no more than 65 years old. Standard errors are clustered at the source country level. Other controls include race/ethnicity, age and age squared. 
immigrant's actual labor supply before migrating. And the effect of the respondent's premigration labor supply remains unchanged at .1. This latter result is interesting, partly because the own labor supply variable can now be interpreted as labor supply relative to the average in one's source country.

Second, columns 5 and 6 of Table 2 show statistically significant negative interaction effects between pre-migration labor supply and the female relative activity rate ranging from -0.222 to -0.193 (with visa category excluded and included, respectively). Based on the estimated interaction effects, Table 3 employs the coefficients from Table 2 to compute the impact of pre-migration labor supply for women migrating from high vs. low female activity rate countries, as well as the impact of female source country activity rate for women who worked before migration vs. those who did not. Table 3 shows that the impact of working before migration (at the conditional average of roughly 2000 hours per year) on U.S. labor supply is 253-262 hours for those coming from low female labor supply countries and 160-163 hours for women from high female labor supply countries.

In addition to studying the variation in the effect of working before migrating on labor supply in the United States, we can use the results of the interaction model to examine variation in the effect of being born in a high female labor supply country vs. a low female labor supply country. As above, we evaluate the impact of coming from a country at the $75^{\text {th }}$ percentile vs. the $25^{\text {th }}$ percentile of female relative labor supply. Among those who did not work before migration, this difference in female relative activity rates increases a woman's labor supply in the United States by 213-259 hours; for those who did work before migrating, the impact of coming from a high vs. a low female relative labor supply country is 123-156. The effects shown in Table 3 are all highly statistically significant as are the negative interaction terms shown in Table 2, columns 5 and 6. Thus, in general, source country female labor supply is more important for those without prior work experience, while prior work experience is more important for those coming from source countries with a more traditional gender division of labor, as indicated by a low female relative activity rate. These comparisons illustrate the degree to which previous labor supply and source country female labor supply can substitute for each other in affecting immigrant women's labor supply in the United States. ${ }^{21}$

Table 2 also contains some interesting results for other factors that influence immigrant women's labor supply in the United States. Looking first at the impact of individual characteristics, we see that, as would be expected, married women work less than single women, other things equal, impacts that are very similar across specifications. We also find that premigration schooling significantly raises post-migration labor supply in all specifications. The estimates suggest that the impact of a college degree vs. a high school degree is 46-69 hours. It is noteworthy that this effect does not change when we control for source country enrollment rates, a specification that, as we noted in our earlier discussion of the impact of own labor

\footnotetext{
${ }^{21}$ We also estimated our models including just the female activity rate, as well as with the male and female activity rates entered separately. In the former, paralleling the results for the activity rate ratio in Table 2, the female activity rate had strong positive effects on women's labor supply and a strong negative interaction with pre-migration labor supply. When both the female and male activity rates were included, we found that the female activity rates raised, and male activity rates lowered, women's labor supply. Moreover, the female activity rate interacted negatively with pre-migration labor supply, while the male activity rate had a positive interaction effect. These findings are just what one would expect, since (controlling for the male rate) the female activity rate is a negative indicator of traditional gender roles, while (controlling for the female rate) the male activity rate is a positive indicator.
} 
Table 3: Effects of Pre-Migration Employment and Source Country Female Labor Supply on Immigrant Women's Annual Work Hours

A. Hours Effects of Pre-Migration Employment vs. No Pre-Migration Employment

\begin{tabular}{lcccc}
\hline & $\begin{array}{c}\text { Low Female Relative Activity Rate } \\
\text { (25th percentile) }\end{array}$ & $\begin{array}{c}\text { Hlgh Female Relative Activity Rate } \\
\text { (75th percentile) }\end{array}$ \\
\hline Premigration Employment & $262.6^{* *}$ & $252.9^{* *}$ & $159.6^{* *}$ & $162.6^{* *}$ \\
\% of Mean Hours & $35.7 \%$ & $34.2 \%$ & $21.7 \%$ & $22.1 \%$ \\
Visa category variables included? & no & yes & no & yes \\
\hline
\end{tabular}

B. Hours Effect of High vs. Low Female Female Activity Rate Country

\begin{tabular}{lcccc}
\hline & No Pre-Migration Work Experience & \multicolumn{2}{c}{ Worked Before Migration } \\
\hline 75th vs. 25th Percentile Female Activity Rate Country & $259.0^{* *}$ & $212.8^{* *}$ & $156.0^{*}$ & $123.5^{*}$ \\
$\%$ of Mean Hours & $35.2 \%$ & $28.9 \%$ & $21.2 \%$ & $16.8 \%$ \\
Visa category variables included? & no & yes & no & yes \\
\hline
\end{tabular}

$* p<.05 * * p<.01$

Note: Estimates are based on Table 2 models interacting pre-migration employment and female relative activity ratio. Premigration hours are set to the mean among those who worked (roughly 2000 hours). The 25 th percentile country is Dominican Republic (relative activity rate $=0.47$ ); and the 75 th percentile country is Sub-Saharan Africa (relative activity rate=.70).

supply, in effect transforms the own schooling variable into one that measures schooling relative to one's source country peers. Years since migration has a positive main coefficient and a negative quadratic coefficient in the analysis of work hours, with a positive derivative for women who have been in the United States for up to 19-20 years (depending on the specification in Table 2), or about $96 \%$ of the population-weighted sample. ${ }^{22}$ As noted earlier, while this effect could be interpreted as assimilation, it may also reflect cohort effects, since we have only one cross-section. And, compared to the omitted "other” visa category, refugees, women with employment visas, and previously unauthorized women have especially high labor supply. ${ }^{23}$

Some source country characteristics besides female labor supply have interesting effects on labor supply as well. First, longer distance to the United States is associated with decreased work hours, implying that the disruption effect outweighs the selection effect discussed above. Second, coming from a country in which English is an official language is associated with longer work hours. Both of these effects were also found for recent immigrants by Blau, Kahn, and Papps (2011). ${ }^{24}$

\footnotetext{
${ }^{22}$ Our basic conclusions were similar using years since the most recent entry into the United States or restricting the sample to those who first migrated within the last five years. Moreover, the findings were robust to defining age and years since migration as quartics and education as a quadratic.

${ }^{23}$ We also estimated separate models for those with employment visas and those with family visas. While the sample sizes were of course smaller, the results for the key variables referring to labor supply before migration, the female relative activity rate ratio, and their interaction were qualitatively similar to those presented in Table 2 . The findings for those with employment visas were especially strong, although we emphasize that visa type may well be endogenous with respect to culture and social capital.

${ }^{24}$ Table 2 shows insignificant effects of gdp per capita on women's work hours. Previous work on international differences in women's labor force participation shows a U-shaped relationship, with women having high labor force participation in countries with either low or high levels of development (measured, for example, by gdp per capita); and, women in countries with middle levels of economic development having the lowest labor force particpation (Goldin 1995; Mammen and Paxson 2000). We tested this notion by including a quadratic term for gdp per capita in our labor supply equation. While the point estimates suggested the same U-shaped relationship found by Goldin (1995) and Mammen and Paxson (2000), the gdp coefficients were insignificant individually and as a pair. This insignificance may not be surprising since we have also controlled for the source country female relative
} 
While the results in Table 2 suggest the presence of substitution effects between own labor supply and source country female labor supply, it is possible that the source country effects reflect overall work preparedness and work orientation rather than the source country division of labor by gender. Table A3 implicitly tests this view by showing results for the same models estimated for men. While prior work experience has a roughly similar effect for men to its effect for women (a coefficient of about .11 in models without an interaction between pre-migration work experience and female relative activity rate), the effects of source country female/male activity ratio and its interaction with pre-migration labor supply are small and insignificant. Thus, our interpretation of these effects for women as reflecting the impact of the source country division of labor by gender would appear valid.

Tables 4-6 continue our investigation into source country female relative participation and immigrant behavior by studying the determinants of log hourly earnings among women who were wage and salary workers and not enrolled in school. We measure prior work experience in these Tables by a dummy variable equaling one for those who were employed before migrating. Using annual hours worked before migrating gave similar but less statistically significant results. ${ }^{25}$ Individuals with wages less than $\$ 1$ or greater than $\$ 250$ per hour were excluded.

The OLS results in Table 4 are qualitatively similar to those in Table 2 for annual work hours but less statistically significant. For example, columns 1, 2 and 4 of Table 4 show models without any interactions between pre-migration work experience and source country female labor supply; in these specifications, the effect of the respondent's own pre-migration labor supply on wages is $4-5 \%$ and only slightly larger than its standard error. Moreover, in columns 3 and 4, the impact of source country female labor supply is positive, but only about the same size as its standard error. However, the results become stronger when we include an interaction term for these two variables, as shown in columns 5 and 6 . For example, in both columns 5 and 6 , the main effect of previous employment is significantly positive, the main effect of the female/male activity ratio is positive and 1.5-2.0 times its standard error, and the interaction effect is negative and 1.4-1.6 times its standard error in absolute value. For comparison purposes, Table A4 shows OLS wage results for men. Focusing on the last two columns, we see that working before migrating, the female relative activity rate ratio, and their interaction all have considerably smaller coefficients than the results for women in Table 4, and the male coefficients are not statistically significant. This comparison suggests that the effects for women of social capital as measured by the female relative activity rate are indeed gender-specific as opposed to reflecting country-specific human capital effects that influence men and women equally.

\footnotetext{
labor force participation rate as well. Importantly, the effects of our key variables-pre-migration work hours, source country female relative activity rate, and their interaction were very similar when we added the quadratic gdp term. To test for the possibility that pre-immigration work experience in more economically developed countries is more transferable to the United States, we also interacted gdp with work hours before migrating; our basic conclusions were unchanged and the interactions were not statistically significant.

${ }^{25}$ Using the dummy for working before migrating in the labor supply equations gave very similar results to the ones reported in Table 2 which used annual work hours worked before migrating.
} 
Table 4: Selected OLS Results for the Determinants of Log Hourly Earnings, Adult Immigrant Women

\begin{tabular}{|c|c|c|c|c|c|c|}
\hline & (1) & $(2)$ & (3) & (4) & (5) & (6) \\
\hline Worked Before Migrating & $\begin{array}{c}0.043 \\
(0.042)\end{array}$ & $\begin{array}{c}0.053 \\
(0.045)\end{array}$ & & $\begin{array}{c}0.053 \\
(0.045)\end{array}$ & $\begin{array}{l}0.238^{*} \\
(0.115)\end{array}$ & $\begin{array}{l}0.191+ \\
(0.102)\end{array}$ \\
\hline Female/Male Activity Ratio in Source Country & & & $\begin{array}{c}0.320 \\
(0.328)\end{array}$ & $\begin{array}{c}0.321 \\
(0.318)\end{array}$ & $\begin{array}{c}0.500 \\
(0.330)\end{array}$ & $\begin{array}{l}0.554+ \\
(0.277)\end{array}$ \\
\hline $\begin{array}{l}\text { Interaction: Worked Before Migrating x } \\
\text { Female/Male Activity Ratio }\end{array}$ & & & & & $\begin{array}{l}-0.315 \\
(0.195)\end{array}$ & $\begin{array}{l}-0.270 \\
(0.195)\end{array}$ \\
\hline Married, Spouse Present & $\begin{array}{l}-0.050 \\
(0.051)\end{array}$ & $\begin{array}{l}-0.060 \\
(0.044)\end{array}$ & $\begin{array}{l}-0.048 \\
(0.042)\end{array}$ & $\begin{array}{l}-0.053 \\
(0.042)\end{array}$ & $\begin{array}{l}-0.055 \\
(0.041)\end{array}$ & $\begin{array}{l}-0.039 \\
(0.026)\end{array}$ \\
\hline Years of Schooling Before Migrating & $\begin{array}{l}0.045^{* *} \\
(0.007)\end{array}$ & $\begin{array}{l}0.040^{* *} \\
(0.006)\end{array}$ & $\begin{array}{l}0.041^{* *} \\
(0.007)\end{array}$ & $\begin{array}{l}0.040^{* *} \\
(0.007)\end{array}$ & $\begin{array}{l}0.039^{* *} \\
(0.006)\end{array}$ & $\begin{array}{l}0.032^{* *} \\
(0.005)\end{array}$ \\
\hline Years of Schooling in US & $\begin{array}{l}0.130^{* *} \\
(0.021)\end{array}$ & $\begin{array}{l}0.132^{* *} \\
(0.017)\end{array}$ & $\begin{array}{c}0.131^{* *} \\
(0.017)\end{array}$ & $\begin{array}{l}0.133^{* *} \\
(0.017)\end{array}$ & $\begin{array}{l}0.132^{* *} \\
(0.017)\end{array}$ & $\begin{array}{l}0.132^{* *} \\
(0.018)\end{array}$ \\
\hline Years Since Migration (YSM) & $\begin{array}{l}0.045^{* *} \\
(0.010)\end{array}$ & $\begin{array}{l}0.050^{* *} \\
(0.011)\end{array}$ & $\begin{array}{l}0.050^{* *} \\
(0.011)\end{array}$ & $\begin{array}{l}0.050^{* *} \\
(0.011)\end{array}$ & $\begin{array}{l}0.050^{* *} \\
(0.010)\end{array}$ & $\begin{array}{l}0.032^{* *} \\
(0.007)\end{array}$ \\
\hline YSM squared (/100) & $\begin{array}{c}-0.121^{* *} \\
(0.037)\end{array}$ & $\begin{array}{c}-0.132^{* *} \\
(0.033)\end{array}$ & $\begin{array}{c}-0.133^{* *} \\
(0.033)\end{array}$ & $\begin{array}{c}-0.132^{* *} \\
(0.034)\end{array}$ & $\begin{array}{c}-0.128^{* *} \\
(0.033)\end{array}$ & $\begin{array}{l}-0.074^{*} \\
(0.032)\end{array}$ \\
\hline Fertility in Source Country & & $\begin{array}{l}-0.026 \\
(0.048)\end{array}$ & $\begin{array}{c}0.001 \\
(0.053)\end{array}$ & $\begin{array}{l}-0.003 \\
(0.051)\end{array}$ & $\begin{array}{l}-0.005 \\
(0.050)\end{array}$ & $\begin{array}{c}0.007 \\
(0.049)\end{array}$ \\
\hline Real GDP in Source Country (1995 \$US/1000) & & $\begin{array}{c}0.000 \\
(0.008)\end{array}$ & $\begin{array}{c}0.002 \\
(0.008)\end{array}$ & $\begin{array}{c}0.002 \\
(0.008)\end{array}$ & $\begin{array}{c}0.002 \\
(0.008)\end{array}$ & $\begin{array}{c}0.004 \\
(0.006)\end{array}$ \\
\hline $\begin{array}{l}\text { Female Secondary Enrollment Rate in Source } \\
\text { Country }\end{array}$ & & $\begin{array}{l}-0.001 \\
(0.003)\end{array}$ & $\begin{array}{l}-0.001 \\
(0.002)\end{array}$ & $\begin{array}{l}-0.002 \\
(0.002)\end{array}$ & $\begin{array}{l}-0.001 \\
(0.002)\end{array}$ & $\begin{array}{l}-0.001 \\
(0.002)\end{array}$ \\
\hline $\begin{array}{l}\text { Female Primary Enrollment Rate in Source } \\
\text { Country }\end{array}$ & & $\begin{array}{c}0.002 \\
(0.002)\end{array}$ & $\begin{array}{c}0.003 \\
(0.003)\end{array}$ & $\begin{array}{c}0.003 \\
(0.002)\end{array}$ & $\begin{array}{c}0.003 \\
(0.002)\end{array}$ & $\begin{array}{c}0.002 \\
(0.002)\end{array}$ \\
\hline $\begin{array}{l}\text { Distance from Source Country to US } \\
\text { (miles/1000) }\end{array}$ & & $\begin{array}{l}-0.018 \\
(0.013)\end{array}$ & $\begin{array}{l}-0.025+ \\
(0.015)\end{array}$ & $\begin{array}{l}-0.026+ \\
(0.014)\end{array}$ & $\begin{array}{l}-0.026+ \\
(0.014)\end{array}$ & $\begin{array}{l}-0.022 \\
(0.014)\end{array}$ \\
\hline English-Speaking Source Country & & $\begin{array}{l}0.345^{*} \\
(0.150)\end{array}$ & $\begin{array}{l}0.291+ \\
(0.155)\end{array}$ & $\begin{array}{l}0.289+ \\
(0.152)\end{array}$ & $\begin{array}{l}0.288+ \\
(0.153)\end{array}$ & $\begin{array}{c}0.129 \\
(0.177)\end{array}$ \\
\hline $\begin{array}{l}\text { English-Official but not English-Speaking } \\
\text { Source Country }\end{array}$ & & $\begin{array}{l}0.343^{* *} \\
(0.113)\end{array}$ & $\begin{array}{l}0.373^{* *} \\
(0.107)\end{array}$ & $\begin{array}{l}0.383^{* *} \\
(0.102)\end{array}$ & $\begin{array}{l}0.387^{* *} \\
(0.103)\end{array}$ & $\begin{array}{l}0.277^{* *} \\
(0.091)\end{array}$ \\
\hline Family Visa & & & & & & $\begin{array}{l}0.154^{* *} \\
(0.039)\end{array}$ \\
\hline Employment Visa & & & & & & $\begin{array}{l}0.639 * * \\
(0.095)\end{array}$ \\
\hline Diversity Visa & & & & & & $\begin{array}{l}-0.088 \\
(0.113)\end{array}$ \\
\hline Refugee Visa & & & & & & $\begin{array}{l}0.111^{*} \\
(0.053)\end{array}$ \\
\hline Legalization Visa & & & & & & $\begin{array}{l}0.211^{* *} \\
(0.071)\end{array}$ \\
\hline $\mathrm{N}$ & 1005 & 1005 & 1005 & 1005 & 1005 & 1005 \\
\hline Adjusted R squared & 0.277 & 0.310 & 0.310 & 0.311 & 0.311 & 0.395 \\
\hline
\end{tabular}

$+p<0.10,{ }^{*} p<0.05,{ }^{* *} p<0.01$

Note: Sample includes those who migrated at age 18 or later and are no more than 65 years old. Standard errors are clustered at the source country level. Sample excludes those currently enrolled in school. Individuals with hourly earnings less than $\$ 1$ or greater than $\$ 250$ are excluded. Other controls include race/ethnicity, age and age squared. Omitted visa category is "other". Self-employed are excluded. 
Table 5 shows wage results for the fully specified model (i.e., including an interaction term for work before migration and female/male activity rate ratio) using a two-step Heckman (1979) estimator to correct for selectivity bias. ${ }^{26}$ The selectivity bias-corrected results are quite similar to the OLS results in Table $4 .{ }^{27}$

Table 6 evaluates the impact of pre-migration labor supply and source country female activity rate on immigrant women's wages based on models including interaction effects. Panel A shows the effect of pre-migration work experience. For women migrating from low female labor supply countries, working before migration raises wages by a statistically significant 8-9\% when we do not control for visa type. The effects are somewhat smaller and not significant when we control for visa type. Overall, the results suggest that pre-migration work experience has a modest labor market return in the United States for women from low female labor supply countries. In contrast, working before moving to the United States has virtually no effect on the wages of women moving from high female labor supply countries. Panel B shows the wage effects of migrating from a high female activity rate country vs. one with a low female activity rate. For women without pre-migration work experience, coming from a high female labor supply country raises wages by $11-13 \%$ using the OLS or Heckman methods, although these effects are significant only when we control for visa type. The effects are noticeably smaller and not statistically significant for those who worked before migrating. ${ }^{28}$ These findings suggest that both pre-migration labor supply and growing up in a work-oriented culture (for women) can both impart skills that are marketable in the US, and that these two sources of human capital act as substitutes in the sense that an increase in one reduces the marginal productivity of the other. While we obtain no evidence that pre-migration work experience raises wages in the United States for those who were born in a country with high levels of female labor force participation, pre-migration work experience has potentially substantial positive effects on US wages for those growing up in a country with low female labor participation. And, similarly, coming from a country with high female relative participation has substantial positive wage effects for women with no pre-migration work experience.

Our finding that source country female relative participation can affect immigrants’ wages (particularly in the case of those who did not work before migrating) can be compared to the findings of Fernández and Fogli (2009) who found that 1950 source country female labor force participation had no impact on second generation women's wages in 1970. There are a number of possible reasons for this difference. Their results refer to women as of 1970, and the nature of female labor force participation and the source countries of immigration have changed dramatically between then and the period for which the NIS collected data-2003 (Blau, Kahn and Papps 2011). Moreover, it is possible that source country social capital really does have an effect on immigrant women's wages but that this effect dissipates by the next generation. ${ }^{29}$ This latter possibility is consistent with the results reported in Antecol (2001). She found a positive

\footnotetext{
26 There is one fewer observation for the Heckman models because they include number of children in the first stage, a variable which is missing for one individual with an observed wage.

${ }^{27}$ Selectivity bias-corrected results for men were virtually identical to those shown in Table A4.

28 Table 5 shows that the coefficient on the selectivity variable ("Inverse Mills Ratio") is not statistically significant in either specification; while this does not prove that selectivity bias is not a problem, a formal statistical test accepts the null hypothesis of no selectivity bias. Indeed, as discussed, the results for our key variables are similar for the Heckman and the OLS models.

29 Below, we consider the possibility that immigrant selectivity could help explain the pattern of wage and labor supply results we have found.
} 
Table 5 : Selected Results for Log Wage Regressions, All Women, With Selectivity Bias Correction (NIS)

\begin{tabular}{lcc}
\hline & $(1)$ & $(2)$ \\
\hline Worked Before Migrating & $0.218^{*}$ & 0.149 \\
& $(0.111)$ & $(0.128)$ \\
Female/Male Activity Ratio in Source Country & 0.454 & $0.474^{*}$ \\
& $(0.309)$ & $(0.203)$ \\
Interaction: Worked Before Migrating x & -0.298 & -0.238 \\
Female/Male Activity Ratio & $(0.186)$ & $(0.187)$ \\
Fertility in Source Country & -0.008 & 0.001 \\
& $(0.047)$ & $(0.043)$ \\
Real GDP in Source Country (\$US/1000) & 0.002 & 0.004 \\
& $(0.007)$ & $(0.006)$ \\
Female Secondary Enrollment Rate in Source Country & -0.002 & -0.001 \\
& $(0.002)$ & $(0.002)$ \\
Female Primary Enrollment Rate in Source Country & 0.003 & 0.002 \\
& $(0.002)$ & $(0.002)$ \\
Distance from Source Country to US & -0.021 & -0.012 \\
(miles/1000) & $(0.013)$ & $(0.024)$ \\
English-Speaking Source Country & $0.297^{*}$ & 0.127 \\
English-Official but not English-Speaking & $(0.146)$ & $(0.162)$ \\
Source Country & $0.362^{* *}$ & $0.227+$ \\
Married, Spouse Present & $(0.090)$ & $(0.119)$ \\
Years of Schooling Before Migrating & -0.036 & -0.008 \\
Years of Schooling in US & $(0.041)$ & $(0.075)$ \\
Years Since Migration (YSM) & $0.038^{* *}$ & $0.029 * *$ \\
YSM squared (/100) & $(0.007)$ & $(0.010)$ \\
& $0.132^{* *}$ & $0.130 * *$ \\
& $(0.017)$ & $(0.018)$ \\
& $0.046^{* *}$ & 0.023 \\
& $(0.012)$ & $(0.022)$ \\
& $-0.116^{* *}$ & -0.052 \\
& $(0.037)$ & $(0.069)$ \\
& -0.0729 & -0.1596 \\
& $(0.0812)$ & $(0.3792)$ \\
& $n 004$ & 1004 \\
\hline
\end{tabular}

$+p<0.10,{ }^{*} p<0.05,{ }^{* *} p<0.01$.

Note: Based on a Heckman two step model that includes number of own children in the first step. Other controls in the wage regressions include age, age squared, and race/ethnicity. 
Table 6: Effects of Pre-Migration Employment and Source Country Female Labor Supply on Immigrant Women's Log Hourly Earnings

\section{A. Effect of Pre-Migration Work Experience}

Low Female Relative Activity Rate HIgh Female Relative Activity Rate (25th percentile)

(75th percentile)

\begin{tabular}{lcccc}
\hline OLS & $.089+$ & 0.064 & 0.016 & 0.001 \\
Selection: Heckman & $.078+$ & 0.037 & 0.009 & -0.018 \\
Visa category variables included? & no & yes & no & yes \\
\hline
\end{tabular}

\section{B. Effect of High vs. Low Female Female Activity Rate Country}

\begin{tabular}{|c|c|c|c|c|}
\hline & \multicolumn{2}{|c|}{ No Pre-Migration Work Experience } & \multicolumn{2}{|c|}{ Worked Before Migration } \\
\hline OLS & 0.116 & $.129+$ & 0.043 & 0.066 \\
\hline Selection: Heckman & 0.106 & $.110^{*}$ & 0.036 & 0.055 \\
\hline Visa category variables included? & no & yes & no & yes \\
\hline
\end{tabular}

$+p<.10 * p<.05 * * p<.01$

Note: Estimates are based on Table 4, columns 5 and 6, and Table 5. Pre-migration hours are set to the mean among those who worked (roughly 2000 hours). The 25th percentile country is Dominican Republic (relative activity rate $=0.47$ ); and the 75th percentile country is Sub-Saharan Africa (relative activity rate $=.70$ ).

correlation between the gender wage gaps of US immigrants and the gender wage gaps in their countries of origin, but no source country effect for second-and-higher generation immigrants.

The results obtained in Tables 6 and 3 suggest that pre-migration work experience and high source country female labor force participation both enhance the wage outcomes of immigrant women and positively affect their work hours in the United States. The hours effects could in principle be due to the impact of these variables in shifting the labor supply curve to right (i.e. by affecting work preferences) or simply due to movements along women's labor supply curves caused by the wage increases. Assuming that the wage effects of these variables represent the impact of social capital, we may ask whether the hours effects can completely be accounted for by movements along the labor supply curve. If so, we would conclude that the impacts of source country female labor supply and pre-migration work experience operate exclusively by enhancing women's social capital. ${ }^{30}$ On the other hand, if the wage effects are insufficient to explain the hours effects, then we conclude that these variables affect women's work preferences in addition to their skills; this would constitute evidence for the impact of culture. Further, if there is evidence of both types of effects, it would also be interesting to estimate the relative importance of culture compared to social capital in accounting for the effect of pre-migration work experience and source country female labor force participation on immigrant women's labor supply in the United States.

To study whether movements along labor supply curves can explain the work hours findings, consider first the effect of pre-migration labor supply on wages and work hours. For women moving from low female labor supply countries, the effect of pre-migration work experience on work hours not controlling for visa type is 35.7\% (Table 3, Panel A Column 1), while the corresponding effect on log wages ranges from 0.078 to 0.089 log points (with and

\footnotetext{
${ }^{30}$ Part of the wage effects obtained in Table 6 for pre-migration labor supply and source country female activity rate may be due to the positive impact of these variables on US labor supply. Thus even some of the wage effects may have been due to cultural influences on immigrant women's preferences.
} 
without the selectivity bias correction, see Table 6), or 8.1-9.3\% (for example, $0.093=\exp (0.089)-1)$. Thus, the hours effect is 3.84 to 4.41 times the wage effect of premigration work experience for women migrating from low female labor supply countries, not controlling for visa type. When we control for visa type, the hours effect is 5.18 to 9.07 times the wage effect for this experiment.

For movements along the labor supply curve to explain the entire work hours effect of pre-migration work experience for those coming from low female labor supply countries, the female labor supply elasticity would need to be in the 3.84 to 9.07 range (or 3.84-4.41 if we focus on the specification that omits visa category). Previous research finds that this parameter was about 0.26-0.32 in the aggregate for women in the United States in 2000 (Blau and Kahn 2007a). In other words, for movements along the labor supply curve to fully explain our results for work hours, the labor supply elasticity of immigrant women would need to be roughly 12 to 35 times that of the full US population of immigrants and natives. If we assume that the estimated elasticities for the population apply to the immigrant women in the NIS sample, only $3-8 \%$ of the hours effect of pre-migration work experience for women migrating from low female labor supply countries is due to movements along the labor supply curve; fully $92-97 \%$ is due to a shift in the labor supply curve. ${ }^{31}$ When we look at the effect of pre-migration work experience for those coming from high female labor supply countries, Table 6 shows that the wage effects for this group are all very small and statistically insignificant. Thus, virtually all of the work hours effect for this group is due to preferences rather than skills.

Looking at the magnitudes of the effects of source country female labor supply, the results suggest that effect of higher source country female labor supply also operates principally to shift the US immigrant women's labor supply function to the right. For example, in the OLS and Heckman models, the hours effects of coming from a high vs. a low female labor supply country range from 2.10 to 5.78 times the wage effects depending on whether one worked before migrating. Again using our plausible value for the female labor supply elasticity, we find that movements along the labor supply curve can explain only $5-14 \%$ of the hours effect of coming from a high vs. a low female supply country. The other $86-95 \%$ of the hours effect is due to a rightward shift of immigrant women's US labor supply function.

This comparison of the wage and hours effects of pre-migration labor supply or source country female labor supply suggests that most of the impact of both of these factors on women's labor supply in the United States is due to shifts of their labor supply functions, although movements along the labor supply curve usually play a role as well. Thus, there is some evidence that while these factors do affect immigrant women's skills, their predominant effect is on women's work orientation and preferences.

Other results for wage determination can be briefly summarized. First, Tables 4 and 5 for women and Table A4 for men show that pre-migration and US schooling both contribute positively to earnings, with, as would be expected, a substantially larger effect of US schooling. Second, in results not shown but available upon request, Black, Hispanic and Asian immigrants earn less than white immigrants, all else equal. Third, growing up in an English-speaking or English-official country or having an employment visa raises earnings for both women and men.

\footnotetext{
31 The 3-8\% range is calculated as follows. The estimates just discussed imply that the hours effect is at least 3.84 times the wage effect. Taking the midpoint of the $0.26-0.32$ range for the labor supply elasticity, the wage results imply that the wage effect raises hours by 0.29 times the percentage wage effect. Since the actual hours effect is 3.84 times the wage effect in this case, then wages can explain only $0.29 / 3.84$, or about $8 \%$ of the hours effect. When the hours effect is 9.07 times the wage effect, wages can explain only $3 \%$ of the hours effect.
} 
Finally, being married has significantly positive effects on male wages and insignificantly negative effects on female wages.

\section{The Possible Role of Selective Migration}

One of our major findings is that source country female labor supply and an immigrant woman's pre-migration labor supply have significantly negative interaction effects on her labor supply and wages in the United States. We have interpreted these results as implying that premigration job experience and the effects of the culture and social capital one accumulates by living in a country where women have high labor force participation act as substitutes in the production of preferences for work (work orientation) and job-related productivity. However, it is also possible that selective migration could help to explain the negative interaction we have found. ${ }^{32}$ We now consider whether such selection could account for our results.

First, consider the implication of the negative interaction effect that high source country female labor supply has a smaller effect on US labor supply and wages for women who worked prior to migration than for women who did not work before migrating. This result could be due to selection if women workers from low female labor supply countries are positively selected relative to women workers from high female labor supply countries. Such a possibility is consistent with results showing a positive cross-country relationship between the gender pay gap and female labor force participation rates (see, Blau and Kahn 2003 and Olivetti and Petrongolo 2008), although, as Blau and Kahn (2003) argue, this finding could also be due to high female labor supply lowering women's relative wages through simple supply effects, as long as men and women are imperfect substitutes in production. Nonetheless, if the selection argument is valid, then it may be that the women from traditional (i.e., low female labor supply) source countries who had previous work experience are an especially positively selected group.

However, now consider those who did not work before migrating. The selection argument outlined above implies that nonparticipants from a high female labor supply country would be more negatively selected than nonparticipants from a low female labor supply country. So selection could not explain why we find especially large positive effects of source country female labor supply for those who did not work prior to migrating. Thus, while selection could help to explain the negative interaction effect by lowering the source country female labor supply effect for those who worked before migrating, it cannot explain the very large source country female participation effect we obtain for those who did not work prior to migrating. This makes it very unlikely that a reasonable selection story can account for our findings.

As we discuss in the next subsection, results from two of our supplementary specifications also suggest that factors other than selection, such as culture and social capital, are part of the explanation for our basic findings. First, we obtain very similar results for married women as for the full sample. Married women are more likely than single women to be tied movers, and, to the extent that is true, selection would be less of an issue for them than otherwise. Second, we obtain similar results when we control for the source country's average

\footnotetext{
${ }^{32}$ It has sometimes been claimed that the second generation is a more appropriate group in which to study these types of relationships because they are not selected. However, second generation outcomes are also impacted by selection, since the second generation consists of children of the possibly self-selected immigrants. That is, their home environments differ from second-generation natives not only due to the impact of immigrant culture but also due to any unmeasured self-selection of their immigrant parents. See, for example, Blau, Kahn, Liu and Papps (2013) for evidence on intergenerational transmission of immigrants' education, labor supply and fertility to their native born children.
} 
emigration rate from the United States, thus implicitly addressing the issue of selective return migration. Finally, in our basic models, we control for distance from the United States, which as Chiswick's (1978) analysis suggests, may be a proxy for the relative labor market return for immigrants that is not captured by other variables in the model.

\section{Supplementary Analyses}

As mentioned above, we performed a number of alternative analyses which, in each case, found similar results to those reported above. For example, Table A5 shows labor supply results for married women. These are of interest in part because one might expect source country culture to exert a stronger pull for married than single women. In addition, as mentioned, married women are more likely to be tied movers than single women are and therefore possibly less influenced by selective migration. Several specifications are shown. The first two columns of Table A5 show the same specifications (excluding and then including the visa category variables, respectively) as those for the basic model on the pooled sample shown in Table 2. The results for the key labor supply, female activity rate, and interaction term are very similar to those in Table 2. Columns 3-5 add information about the immigrant's husband as well as controlling for number of own children. Roughly $82 \%$ of the sample of married women are married to immigrant men, and, of this group, fully 92\% are married to men born in the same country. We therefore do not control for husband's source country information, although we control for whether the husband is an immigrant (Column 3) and additionally whether he is an immigrant from the same source country as the respondent (Column 4). ${ }^{33}$ Finally, in Column 5, we restrict the sample to women whose husbands were immigrants born in the same country they were. The results for the key labor supply, female activity rate, and interaction term variables remain broadly similar to those presented in Table 2 , although the magnitudes and significance levels of the effect of pre-migration labor supply and its interaction with female relative activity are weaker for the restricted sample of married women with spouses from the same country. Importantly, the main effect of the female relative activity rate remains virtually unchanged, indicating a very large effect of source country female labor supply on married immigrant women, even controlling for their pre-migration work status.

We further investigated married women's labor supply by restricting the sample of married women to those who were married when they migrated, where we define the time of migration in the two ways mentioned above (i.e., either the first time or the most recent time migrating to the United States). ${ }^{34}$ These groups comprise about $80 \%$ of currently married immigrant women and, as mentioned earlier, are the sample most likely to consist of tied movers. The results were broadly similar to those in Table A5: the main effect of female relative activity rate remains strongly positive and significant; the main effect of previous labor supply remains positive, and the interaction between this variable and female relative activity rate remains negative.

\footnotetext{
${ }^{33}$ While the NIS has some information on when a respondent's immigrant spouse came to the United States, the information is missing for about $29 \%$ of the immigrant spouses. When we estimated the basic models in Table A5 including the spouse's years since migration and its square, the results were similar to those in Table A5. The main effect of the spouse's years since migration was negative, with a positive quadratic term; overall, spouse's years since migration had a negative partial derivative for almost all of the sample.

34 This group was identified using information in the NIS on how long the woman and her husband had lived together. Thus, this group is restricted to women who were married to (or living with) their current spouse at the time of migrating to the United States.
} 
In addition, in results not shown but available on request, we attempted the following alternative analyses of labor supply. In each case the findings were very similar to those presented above, giving us confidence that our conclusions about source country culture hold across different groups and under different specifications. First, labor supply results were similar for single women; less educated women (those with less than twelve years of schooling); and highly educated women (those with at least twelve years of schooling). Second, findings were similar when we used labor force participation or employment as the dependent variable in logit analyses. Third, we added each source country's female 1980-90 emigration rate as an explanatory variable in the basic labor supply models, and the results were unchanged. The emigration rate had a positive, but insignificant effect on United States labor supply. The positive impact is consistent with the positive selection among stayers, although this effect did not influence our basic conclusions about pre-migration labor supply and source country female participation. Therefore, possible plans for return migration are not part of the explanation for the basic labor supply results in Tables 2 and 3. Fourth, we controlled for religious tradition and attendance at religious services in the basic labor supply model. The results, also available from the authors on request, for pre-migration employment and source country female labor supply were again unchanged. The religious tradition variables all had negative effects relative to the omitted category-No Religion, and the frequency of attendance effects were all small and insigificant. In addition, the basic results were unchanged when we controlled for region or the five major immigrant source countries (China, India, Mexico, the Philippines, and El Salvador). Thus, the basic labor supply results shown in Tables 2 and 3 also hold within regions, major source countries, and religious groups. Finally, in our basic analyses of labor supply, we additionally controlled for schooling in the United States. The results were again very similar.

\section{Conclusions}

In this paper we use data from the New Immigrant Survey to investigate the impact of immigrant women's own labor supply prior to migrating and source country female labor supply to provide evidence on the role of culture and social capital in affecting their labor supply and wages in the United States. We find, as expected, that women who migrate from countries with relatively high levels of female labor supply work more in the United States. Importantly, most of this effect remains when we further control for each woman's own labor supply prior to migrating, which itself also strongly positively affects labor supply in the United States. Moreover, we find a significantly negative interaction between pre-migration labor supply and source country female labor supply. This means that the impact of source country female labor supply is much stronger for those who did not themselves work for pay before migrating than among those with work experience in their source country, while the impact of pre-migration work experience is larger for those from source countries with low female labor supply than for those from high female labor supply countries. We obtain broadly similar effects analyzing the determinants of hourly earnings among the employed in the United States, although the effects are not always significant.

These results suggest an important role for source country environment in affecting immigrant women's labor supply, since the effect of source country female labor supply on immigrant women's work hours in the United States is still strong even controlling for the immigrant's own pre-migration labor supply. The negative interaction effects between previous work experience and source country female labor supply on immigrant women's US work hours and wages suggest that culture and social capital can substitute for individual job-related human 
capital in affecting preparedness for work and work orientation in the United States. While either culture (preferences) or social capital shaped by the source country environment could explain this pattern of findings, we show that, given plausible values of labor supply elasticities, most of the impact of source country female labor supply is not due to its impact on wages, suggesting that culture rather than social capital is the primary factor accounting for the source country effect. 


\section{References}

Ahmed, Bashir and J. Gregory Robinson. 1994. "Estimates of Emigration of the Foreign-Born Population: 1980-1990.” Working Paper No. 9, U.S. Bureau of the Census Population Division (December).

Akresh, Ilana Redstone. 2008. “Occupational Trajectories of Legal US Immigrants:

Downgrading and Recovery.” Population and Development Rev. 34 (September): 435456.

Antecol, Heather. 2000. "An Examination of Cross-Country Differences in the Gender Gap in Labor Force Participation Rates.” Labour Econ. 7 (July): 409-426.

Antecol, Heather. 2001. "Why Is There Interethnic Variation in the Gender Wage Gap? The Role of Cultural Factors.” J. Human Resources 36 (Winter): 119-143.

Barro, Robert J., and Jong-Wha Lee. 1994. “Sources of Economic Growth.” CarnegieRochester Conference Series on Public Policy 40: 1-46.

Blau, Francine D. 1992. "The Fertility of Immigrant Women: Evidence from High-Fertility Source Countries.” In Immigration and the Work Force: Economic Consequences for the United States and Source Areas, edited by George J. Borjas and Richard B. Freeman. Chicago: Univ. Chicago Press.

Blau, Francine D. and Lawrence M. Kahn. 2003. “Understanding International Differences in the Gender Pay Gap.” J. Labor Econ. 21 (January): 106-144.

Blau, Francine D. and Lawrence M. Kahn. 2006. “The U.S. Gender Pay Gap in the 1990s: Slowing Convergence.” Indus. and Labor Relations Rev. 60 (October): 45-66.

Blau, Francine D. and Lawrence M. Kahn. 2007a. "Changes in the Labor Supply Behavior of Married Women: 1980-2000.” J. Labor Econ. 25 (July): 393-438.

Blau, Francine D. and Lawrence M. Kahn. 2007b. "Gender and Assimilation among Mexican Americans.” In Mexican Immigration to the United States, edited by George Borjas. Chicago: Univ. Chicago Press.

Blau, Francine D., Lawrence M. Kahn, Albert Yung-Hsu Liu, and Kerry L. Papps. 2013. “The Transmission of Women's Fertility, Human Capital, and Work Orientation Across Immigrant Generations.” J. Population Econ. 26 (April): 405-435.

Blau, Francine D., Lawrence M. Kahn and Kerry L. Papps. 2011. “Gender, Source Country Characteristics and Labor Market Assimilation Among Immigrants: 1980-2000.” Rev. Econ. and Statis. 93 (February): 43-58. 
Bleakley, Hoyt and Aimee Chin. 2004. "Language Skills and Earnings: Evidence from Childhood Immigrants.” Rev. Econ. and Statis. 86 (May): 481-496.

Borjas, George J. 1985. “Assimilation, Changes in Cohort Quality, and the Earnings of Immigrants.” J. Labor Econ. 3 (October): 463-489.

Borjas, George J. 1992. “Ethnic Capital and Intergenerational Mobility.” Q.J.E. 107 (February): 123-150.

Chiswick, Barry R. 1978. "The Effect of Americanization on the Earnings of Foreign Born Men.” J.P.E. 86 (October): 897-921.

Coleman, James S. 1988. "Social Capital in the Creation of Human Capital.” American J. Sociology 94 (Supplement): S95-S120.

Cooke, Thomas J., Paul Boyle, and Kenneth Couch. 2009. “A Longitudinal Analysis of Family Migration and the Gender Gap in Earnings in the United States and Great Britain.” Demography 46 (February): 147-167.

Dasgupta, Partha. 2008. “Social Capital.” In The New Palgrave Dictionary of Economics, $2^{\text {nd }}$ edition, edited by Steven N. Durlauf and Lawrence E. Blume. The New Palgrave Dictionary of Economics Online. Palgrave Macmillan.

Fernández, Raquel and Alessandra Fogli. 2006."Fertility: The Role of Culture and Family Experience.” J. European Econ. Assoc. 4 (April-May): 552-561.

Fernández, Raquel and Alessandra Fogli. 2009. “Culture: An Empirical Investigation of Beliefs, Work, and Fertility.”American Econ. J.: Macroeconomics 1 (January): 146-177.

Goldin, Claudia. 1995. "The U-Shaped Female Labor Force Function in Economic Development and Economic History.” In Investment in Women's Human Capital, edited by T. Paul Schultz. Chicago: Univ. Chicago Press.

Heckman, James J. 1979. “Sample Selection Bias as a Specification Error.” Econometrica 47 (January): 153-162.

Hoefer, Michael, Nancy Rytina, and Christopher Campbell. 2007. "Estimates of the Unauthorized Immigrant Population Residing in the United States: January 2006.” Report, U.S. Department of Homeland Security, Office of Immigration Statistics Policy Directorate Report (August).

Jaeger, David A.. 1997. "Reconciling the Old and New Census Bureau Education Questions: Recommendations for Researchers.” J. Business \& Econ. Statis. 15 (July): 300-309.

Jasso, Guillermina, Douglas S. Massey, Mark R. Rosenzweig, and James P. Smith. Forthcoming. "The U.S. New Immigrant Survey: Overview and Preliminary Results Based on the New-Immigrant Cohorts of 1996 and 2003.” In Immigration Research and Statistics Service Workshop on Longitudinal Surveys and Cross-Cultural Survey Design: 
Workshop Proceedings, edited by Beverley Morgan and Ben Nicholson. London: Crown Publishing.

Lubotsky, Darren. 2007. "Chutes or Ladders? A Longitudinal Analysis of Immigrant Earnings.” J.P.E. 115 (October): 820-867.

Mammen, Kristin and Christina Paxson. 2000. "Women’s Work and Economic Development." J. Econ. Perspectives 14 (Fall): 141-164.

Mincer, Jacob. 1978. “Family Migration Decisions.” J.P.E. 86 (October): 749-73.

Neal, Derek. 2004. “The Measured Black-White Wage Gap among Women Is Too Small.” J.P.E. 112 (February Supplement): S1-S28.

Neal, Derek A. and William R. Johnson. 1996. "The Role of Premarket Factors in Black-White Wage Differences.” J.P.E. 104 (October): 869-895.

Olivetti, Claudia and Barbara Petrongolo. 2008. "Unequal Pay or Unequal Employment? A Cross-Country Analysis of Gender Gaps.” J. Labor Econ. 26 (October): 621-654.

Redstone, Ilana and Douglas S. Massey. 2004. "An Analysis of the U.S. Census Question on Immigrants’ Year of Arrival.” Demography 41 (November): 721-738.

United Nations Statistics Division (UNSD). "Fertility Rate (13700): Total Fertility Rate” (UN Pop. Div. Quinquennial Estimates and Projections). http://unstats.un.org/unsd/cdb/cdb_series_xrxx.asp?series_code=13700.

United Nations Statistics Division (UNSD). “GDP (22918): Gross Domestic Product at Market Prices, Constant US\$” (World Bank Estimates). http://unstats.un.org/unsd/cdb/cdb_series_xrxx.asp?series_code=29918.

United Nations Statistics Division (UNSD). “Population (13660): Population Total” (UN Pop. Div. Annual Estimates and Projections) [code 13660]. http://unstats.un.org/unsd/cdb/cdb_series_xrxx.asp?series_code=13660.

United Nations Statistics Division (UNSD). “Economic Activity Rate (4270): Economic Activity Rate by Sex, Thirteen Age Groups, 1950-2010” (ILO Estimates and Projections). http://unstats.un.org/unsd/cdb/cdb_series_xrxx.asp?series_code=4270.

United Nations Statistics Division (UNSD). “Economically Activity Population (4230): Economically Active Population by Sex, Thirteen Age Groups, 1950-2010” (ILO Estimates and Projections). http://unstats.un.org/unsd/cdb/cdb_series_xrxx.asp?series_code=4230.

U.S. Arms and Control Disarmament Agency. Various Issues. World Military Expenditures and Arms Transfers. 
U.S. Department of Homeland Security. 2012. Yearbook of Immigration Statistics: 2011. Washington, D.C.: U.S. Department of Homeland Scurity, Office of Immigration Statistics.

U.S. Department of Justice. Various Issues. Annual Report of the Immigration and Naturalization Service. Washington, D.C.: U.S. Government Printing Office.

U.S. Department of State. Various Issues. World Military Expenditures and Arms Transfers.

U.S. Immigration and Naturalization Service. Various Issues. Statistical Yearbook of the Immigration and Naturalization Service. Washington, D.C.: U.S. Government Printing Office.

Wilson, William Julius. 1987. The Truly Disadvantaged: The Inner City, the Underclass, and Public Policy. Chicago Univ. of Chicago Press.

World Almanac and Book of Facts. 1999. New York: World Almanac Books. 


\section{Appendix: Construction of the Source Country Variables}

The source country characteristics described below were collected at five-year intervals for the period 1950 to 2000 and were originally used in Blau, Kahn and Papps (2011). This initial data set was developed to match the source country listings in US Census data. To form a consistent list of source countries, we combine some countries which were not available in some Census years (e.g., subsets of countries in Africa, the Pacific Islands, and the West Indies) and countries that split or combined between 1980 and 2000 (e.g., the former USSR countries, East and West Germany, former Czechoslovakia, and former Yugoslavia). Some countries were combined because data on source country characteristics were only available in a combined form. The data set includes 106 source countries in total. The characteristics for each composite group are the average values over constituent countries weighted by each country's population age 18 to 65 from the 2000 Census 1\% extract. Due to missing values of source country variables in some years, we have, in cases, interpolated for intervening years, used earliest (most recent) values for preceding (subsequent) years, and imputed source country characteristics from neighboring countries. Source country characteristics were matched to arrival cohorts as follows: 1950-1959: 1955; 1960-1964: 1960; 1965-1969: 1965; 1970-1974: 1970; 1975-1979: 1975; 1980-1984: 1980; 1985-1990: 1985; 1991-1994: 1990; 1995-2000: 1995.

We then merged the data set into the NIS's list of source countries. In some cases, we had to aggregate countries from the source country data set, since the NIS includes only 27 source countries or country groups. In the aggregation, we used separate weighted averages by gender by source country for immigrants who arrived in the last 5 years, taken from the 2000 Census of Population. The averages used Census sampling weights. 
Source Country Characteristics: Definitions and Sources

\begin{tabular}{|c|c|}
\hline Variable & Description \\
\hline Fertility & $\begin{array}{l}\text { Total fertility rate: the number of children that would be born per woman, assuming no } \\
\text { female mortality at child bearing ages and the age-specific fertility rates of a specified } \\
\text { country and reference period. The data are available between } 1955 \text { and } 2000 \text { at five } \\
\text { year intervals. Source: United Nations Statistics Division, Series } 13700 \text { (2006). }\end{array}$ \\
\hline GDP per Capita & $\begin{array}{l}\text { GDP per capita (1995 US \$): GDP is an aggregate measure of production equal to the } \\
\text { sum of the gross values added of all resident institutional units engaged in production. } \\
\text { The total population of a country may comprise either all usual residents of the } \\
\text { country (de jure population) or all persons present in the country (de facto population) } \\
\text { at the time of the census. The data are available annually between } 1960 \text { and } 2000 . \\
\text { Source: United Nations Statistics Division, Series } 29918 \text { and } 13660 \text { (2006), with } \\
\text { supplemental data from U.S. Arms and Control Disarmament Agency and U.S. } \\
\text { Department of State, World Military Expenditures and Arms Transfers (various } \\
\text { issues). }\end{array}$ \\
\hline $\begin{array}{l}\text { Female/Male Activity } \\
\text { Rate }\end{array}$ & $\begin{array}{l}\text { Female LFP / Male LFP: Economically active population ("usually active" or } \\
\text { "currently active" (currently active is also known as "the labor force")) comprises all } \\
\text { persons who furnish the supply of labor for the production of economic goods and } \\
\text { services (employed and unemployed, including those seeking work for the first time), } \\
\text { as defined by the System of National Accounts (SNA). The rates are calculated for } \\
\text { individuals age } 15 \text { and up. The data are available between } 1950 \text { and } 2000 \text { at ten year } \\
\text { intervals and in } 1995 \text {. Source: United Nations Statistics Division, Series } 4270 \text { and } \\
4230 \text { (2006). }\end{array}$ \\
\hline $\begin{array}{l}\text { Primary School } \\
\text { Enrollment Rate }\end{array}$ & $\begin{array}{l}\text { Female or male primary school enrollment rate: Gross enrollment ratio is the ratio of } \\
\text { total enrollment, regardless of age, to the population of the age group that officially } \\
\text { corresponds to that level of education in question. The World Bank data are available } \\
\text { in 1970, 1975, 1980, 1985, and 1990-1998; Barro-Lee data are available between } 1960 \\
\text { and 1985 at five year intervals. Source: World Bank World Development Indicators } \\
\text { CD-Rom, Series SE.PRM.ENRR.FE (2002), with supplemental data from Barro and } \\
\text { Lee (1994). }\end{array}$ \\
\hline $\begin{array}{l}\text { Secondary School } \\
\text { Enrollment Rate }\end{array}$ & $\begin{array}{l}\text { Female or male secondary school enrollment rate: Gross enrollment ratio is the ratio of } \\
\text { total enrollment, regardless of age, to the population of the age group that officially } \\
\text { corresponds to that level of education in question. The World Bank data are available } \\
\text { in 1970, 1975, 1980, 1985, and 1990-1998; Barro-Lee data are available between } 1960 \\
\text { and 1985 at five year intervals. Source: World Bank World Development Indicators } \\
\text { CD-Rom, Series SE.SEC.ENRR.FE (2002), with supplemental data from Barro and } \\
\text { Lee (1994). }\end{array}$ \\
\hline $\begin{array}{l}\text { English-Speaking } \\
\text { Country }\end{array}$ & $\begin{array}{l}\text { English speaking country. Source: Bleakley and Chin (2004); their data were from the } \\
\text { World Almanac and Book of Facts (1999). }\end{array}$ \\
\hline $\begin{array}{l}\text { English Official } \\
\text { Language }\end{array}$ & $\begin{array}{l}\text { English is an official language of the country (for non-English-Speaking countries). } \\
\text { Source: Bleakley and Chin (2004); their data were from the World Almanac and Book } \\
\text { of Facts (1999). }\end{array}$ \\
\hline Emigration Rate & $\begin{array}{l}\text { Annual female emigration rate: the annual number of female emigrants between } 1980 \\
\text { and } 1990 \text { divided by the average of the } 1980 \text { and } 1990 \text { female immigrant populations. } \\
\text { Source: Annual emigration estimates by country from Ahmed and Robinson (1994). }\end{array}$ \\
\hline Distance to US & $\begin{array}{l}\text { Distance to the U.S. (miles): computed as the distance between the capital of the } \\
\text { foreign country and the closest of three U.S. gateways - New York, Los Angeles or } \\
\text { Miami. See http://www.indo.com/distance/ and } \\
\text { http://www.cia.gov/cia/publications/factbook }\end{array}$ \\
\hline
\end{tabular}


Table A1: Cell Sizes and Weighted Incidence by Source Country and Gender

\begin{tabular}{|c|c|c|c|c|}
\hline & \multicolumn{2}{|c|}{ Men } & \multicolumn{2}{|c|}{ Women } \\
\hline & \multicolumn{3}{|c|}{ Weighted } & \multirow{2}{*}{$\begin{array}{l}\text { Weighted } \\
\text { Incidence }\end{array}$} \\
\hline & Sample Size & Incidence & Sample Size & \\
\hline Africa (sub-Saharan) & 160 & 0.051 & 115 & 0.035 \\
\hline Canada & 40 & 0.016 & 44 & 0.018 \\
\hline China & 136 & 0.043 & 143 & 0.051 \\
\hline Colombia & 31 & 0.018 & 53 & 0.025 \\
\hline Cuba & 49 & 0.023 & 54 & 0.019 \\
\hline Dominican Republic & 33 & 0.018 & 51 & 0.018 \\
\hline East and South Asia/Pacific & 196 & 0.062 & 206 & 0.076 \\
\hline El Salvador & 113 & 0.057 & 132 & 0.048 \\
\hline Ethiopia & 85 & 0.019 & 54 & 0.013 \\
\hline Europe. Central Asia & 270 & 0.097 & 294 & 0.087 \\
\hline Guatemala & 52 & 0.026 & 58 & 0.021 \\
\hline Haiti & 39 & 0.020 & 50 & 0.020 \\
\hline India & 336 & 0.085 & 248 & 0.085 \\
\hline Jamaica & 36 & 0.023 & 40 & 0.015 \\
\hline Korea & 51 & 0.016 & 55 & 0.019 \\
\hline Latin America, Caribbean & 141 & 0.071 & 145 & 0.057 \\
\hline Mexico & 210 & 0.126 & 355 & 0.154 \\
\hline Middle East, North Africa & 139 & 0.051 & 100 & 0.039 \\
\hline Nigeria & 61 & 0.017 & 57 & 0.014 \\
\hline Oceania & 10 & 0.004 & 12 & 0.005 \\
\hline Peru & 24 & 0.008 & 42 & 0.016 \\
\hline Philippines & 111 & 0.046 & 249 & 0.069 \\
\hline Poland & 89 & 0.026 & 79 & 0.016 \\
\hline Russia & 40 & 0.015 & 48 & 0.016 \\
\hline Ukraine & 55 & 0.017 & 47 & 0.012 \\
\hline United Kingdom & 45 & 0.016 & 20 & 0.007 \\
\hline Vietnam & 70 & 0.031 & 110 & 0.047 \\
\hline Total & 2622 & & 2861 & \\
\hline
\end{tabular}

Source: NIS. Sample includes those who migrated at age 18 or later.

Weighted incidence uses NIS sampling weights. 
Table A2: Means for Recent Immigrants Using the 5\% Sample of the 2000 Census and the 2005 ACS (ages 18-65)

\begin{tabular}{|c|c|c|c|c|c|c|}
\hline \multirow[b]{3}{*}{ Variable } & \multicolumn{2}{|c|}{2000 Census } & \multicolumn{2}{|c|}{2005 ACS } & \multicolumn{2}{|c|}{ NIS } \\
\hline & Male & Female & Male & Female & Male & Female \\
\hline & Mean & Mean & Mean & Mean & Mean & Mean \\
\hline Employed & 0.716 & 0.430 & 0.815 & 0.461 & 0.724 & 0.407 \\
\hline In Labor Force & 0.763 & 0.486 & 0.862 & 0.523 & 0.907 & 0.594 \\
\hline Hours Worked & $1,435.7$ & 764.4 & $1,634.4$ & 826.4 & 1399.3 & 735.5 \\
\hline Age & 32.35 & 33.46 & 33.03 & 33.99 & 38.17 & 37.93 \\
\hline Married - Spouse Present & 0.404 & 0.588 & 0.411 & 0.595 & 0.780 & 0.785 \\
\hline Number of Children in Household & 0.600 & 0.949 & 0.591 & 0.925 & 1.531 & 1.757 \\
\hline In(Hourly Earnings) & 2.39 & 2.23 & 2.42 & 2.29 & 2.494 & 2.290 \\
\hline Educational Attainment & 11.75 & 11.96 & 11.82 & 12.27 & 13.18 & 12.28 \\
\hline Latin America and Caribbean & 0.548 & 0.487 & 0.605 & 0.520 & 0.389 & 0.393 \\
\hline Europe and Central Asia & 0.131 & 0.143 & 0.094 & 0.112 & 0.171 & 0.137 \\
\hline South and East Asia & 0.212 & 0.264 & 0.195 & 0.258 & 0.282 & 0.347 \\
\hline Sub-Saharan Africa & 0.038 & 0.038 & 0.044 & 0.043 & 0.087 & 0.062 \\
\hline Sample size & 112,876 & 103,825 & 20,000 & 20,579 & 2,622 & 2,861 \\
\hline
\end{tabular}

Notes: Sample is restricted to individuals who migrated to the US within the last 5 years, were at least 18 years old when they migrated, are currently not older than 65 , do not have an allocated source country. Means are weighted by the Census provided person weight. Education categories are constructed according to Jaeger (1997). Individuals with any selfemployment income, with a self-employment worker class, or with hourly earnings below $\$ 1 / \mathrm{hr}$ or abor $\$ 250 / \mathrm{hr}$ are excluded from hourly earnings mean. Children variable for the NIS refers to own children. 
Table A3: Selected OLS Results for the Determinants of Annual Work Hours (including zeroes), Adult Immigrant Men

\begin{tabular}{|c|c|c|c|c|c|c|}
\hline & (1) & (2) & (3) & (4) & (5) & (6) \\
\hline Annual Work Hours Before Migrating & $\begin{array}{l}0.108 * * \\
(0.024)\end{array}$ & $\begin{array}{l}0.107^{* *} \\
(0.025)\end{array}$ & & $\begin{array}{l}0.107 * * \\
(0.025)\end{array}$ & $\begin{array}{l}0.041 \\
(0.087)\end{array}$ & $\begin{array}{l}0.030 \\
(0.088)\end{array}$ \\
\hline Female/Male Activity Ratio in Source Country & & & $\begin{array}{l}67.563 \\
(310.597)\end{array}$ & $\begin{array}{l}186.970 \\
(325.281)\end{array}$ & $\begin{array}{l}5.628 \\
(462.931)\end{array}$ & $\begin{array}{l}-118.371 \\
(372.161)\end{array}$ \\
\hline $\begin{array}{l}\text { Interaction: Annual Work Hours Before } \\
\text { Migrating x Female/Male Activity Ratio }\end{array}$ & & & & & $\begin{array}{l}0.114 \\
(0.127)\end{array}$ & $\begin{array}{l}0.138 \\
(0.128)\end{array}$ \\
\hline Married, Spouse Present & $\begin{array}{l}220.940^{* *} \\
(60.521)\end{array}$ & $\begin{array}{l}206.756^{* *} \\
(61.746)\end{array}$ & $\begin{array}{l}225.436^{* *} \\
(66.242)\end{array}$ & $\begin{array}{l}206.947^{* *} \\
(61.522)\end{array}$ & $\begin{array}{l}206.728^{* *} \\
(61.621)\end{array}$ & $\begin{array}{l}152.399 * \\
(54.953)\end{array}$ \\
\hline Years of Schooling Before Migrating & $\begin{array}{l}24.477^{* *} \\
(6.992)\end{array}$ & $\begin{array}{l}22.000 * * \\
(7.696)\end{array}$ & $\begin{array}{l}23.461^{* *} \\
(7.212)\end{array}$ & $\begin{array}{l}22.043^{* *} \\
(7.737)\end{array}$ & $\begin{array}{l}22.114^{* *} \\
(7.676)\end{array}$ & $\begin{array}{l}20.395^{*} \\
(8.326)\end{array}$ \\
\hline Years Since Migration (YSM) & $\begin{array}{l}138.731^{* *} \\
(21.076)\end{array}$ & $\begin{array}{l}137.706^{* *} \\
(21.514)\end{array}$ & $\begin{array}{l}134.050^{* *} \\
(21.057)\end{array}$ & $\begin{array}{l}138.476^{* *} \\
(21.628)\end{array}$ & $\begin{array}{l}138.714^{* *} \\
(21.458)\end{array}$ & $\begin{array}{l}98.596 * * \\
(21.147)\end{array}$ \\
\hline YSM squared (/100) & $\begin{array}{l}-389.934^{* *} \\
(87.036)\end{array}$ & $\begin{array}{l}-394.820^{* *} \\
(91.244)\end{array}$ & $\begin{array}{l}-391.416^{* *} \\
(92.291)\end{array}$ & $\begin{array}{l}-397.371 * * \\
(92.258)\end{array}$ & $\begin{array}{l}-398.325^{* *} \\
(91.911)\end{array}$ & $\begin{array}{l}{ }^{*}-262.579 * * \\
(84.413)\end{array}$ \\
\hline Fertility in Source Country & & $\begin{array}{l}82.233^{*} \\
(32.116)\end{array}$ & $\begin{array}{l}96.321+ \\
(48.398)\end{array}$ & $\begin{array}{l}99.771 * \\
(45.452)\end{array}$ & $\begin{array}{l}99.456 * \\
(45.798)\end{array}$ & $\begin{array}{l}109.436^{* *} \\
(37.081)\end{array}$ \\
\hline Real GDP in Source Country (\$US/1000) & & $\begin{array}{l}6.077 \\
(7.464)\end{array}$ & $\begin{array}{l}5.891 \\
(7.205)\end{array}$ & $\begin{array}{l}6.964 \\
(7.320)\end{array}$ & $\begin{array}{l}7.017 \\
(7.380)\end{array}$ & $\begin{array}{l}12.193 * \\
(4.721)\end{array}$ \\
\hline $\begin{array}{l}\text { Male Secondary Enrollment Rate in Source } \\
\text { Country }\end{array}$ & & $\begin{array}{l}5.424+ \\
(3.014)\end{array}$ & $\begin{array}{l}6.098+ \\
(3.277)\end{array}$ & $\begin{array}{l}5.689+ \\
(3.180)\end{array}$ & $\begin{array}{l}5.622+ \\
(3.156)\end{array}$ & $\begin{array}{l}4.265+ \\
(2.343)\end{array}$ \\
\hline $\begin{array}{l}\text { Male Primary Enrollment Rate in Source } \\
\text { Country }\end{array}$ & & $\begin{array}{l}-1.139 \\
(2.654)\end{array}$ & $\begin{array}{l}-1.347 \\
(2.528)\end{array}$ & $\begin{array}{l}-0.945 \\
(2.664)\end{array}$ & $\begin{array}{l}-0.831 \\
(2.612)\end{array}$ & $\begin{array}{l}-1.353 \\
(1.814)\end{array}$ \\
\hline $\begin{array}{l}\text { Distance from Source Country to US } \\
\text { (miles/1000) }\end{array}$ & & $\begin{array}{l}-2.986 \\
(20.570)\end{array}$ & $\begin{array}{l}-3.622 \\
(21.902)\end{array}$ & $\begin{array}{l}-8.523 \\
(22.671)\end{array}$ & $\begin{array}{l}-8.124 \\
(22.890)\end{array}$ & $\begin{array}{l}-1.884 \\
(17.200)\end{array}$ \\
\hline English-Speaking Source Country & & $\begin{array}{l}92.114 \\
(155.689)\end{array}$ & $\begin{array}{l}61.108 \\
(160.986)\end{array}$ & $\begin{array}{l}56.720 \\
(161.275)\end{array}$ & $\begin{array}{l}62.312 \\
(159.778)\end{array}$ & $\begin{array}{l}53.667 \\
(132.506)\end{array}$ \\
\hline $\begin{array}{l}\text { English-Official but not English-Speaking } \\
\text { Source Country }\end{array}$ & & $\begin{array}{l}34.388 \\
(89.448)\end{array}$ & $\begin{array}{l}35.504 \\
(112.746)\end{array}$ & $\begin{array}{l}54.451 \\
(110.617)\end{array}$ & $\begin{array}{l}52.127 \\
(112.703)\end{array}$ & $\begin{array}{l}-33.772 \\
(67.415)\end{array}$ \\
\hline Family Visa & & & & & & $\begin{array}{l}354.804^{* *} \\
(92.668)\end{array}$ \\
\hline Employment Visa & & & & & & $\begin{array}{l}642.683^{* *} \\
(158.680)\end{array}$ \\
\hline Diversity Visa & & & & & & $\begin{array}{l}-43.706 \\
(85.641)\end{array}$ \\
\hline Refugee Visa & & & & & & $\begin{array}{l}759.675^{* *} \\
(103.749)\end{array}$ \\
\hline Legalization Visa & & & & & & $\begin{array}{l}309.345^{* *} \\
(106.442)\end{array}$ \\
\hline $\mathrm{N}$ & 2622 & 2622 & 2622 & 2622 & 2622 & 2622 \\
\hline Adjusted R squared & 0.222 & 0.226 & 0.214 & 0.226 & 0.226 & 0.257 \\
\hline
\end{tabular}

$+p<0.10, * p<0.05, * * p<0.01$

Note: Sample includes those who migrated at age 18 or later and who are currently no more than 65 years old. Standard errors are clustered at the source country level. Other controls include race/ethnicity, age and age squared. 
Table A4: Selected OLS Results for the Determinants of Log Hourly Earnings, Adult Immigrant Men

\begin{tabular}{|c|c|c|c|c|c|c|}
\hline & (1) & (2) & (3) & (4) & (5) & (6) \\
\hline \multirow[t]{2}{*}{ Worked Before Migrating } & 0.044 & 0.041 & & 0.044 & 0.020 & -0.079 \\
\hline & $(0.033)$ & $(0.032)$ & & $(0.032)$ & (0.089) & (0.089) \\
\hline \multirow[t]{2}{*}{ Married, Spouse Present } & $0.113^{* *}$ & $0.102^{*}$ & $0.106^{*}$ & $0.102^{*}$ & $0.102 *$ & $0.111^{* *}$ \\
\hline & (0.039) & $(0.038)$ & $(0.038)$ & $(0.038)$ & $(0.038)$ & $(0.038)$ \\
\hline \multirow[t]{2}{*}{ Years of Schooling Before Migrating } & $0.054^{* *}$ & $0.047^{* *}$ & $0.047^{* *}$ & $0.047^{* *}$ & $0.047^{* *}$ & $0.037^{* *}$ \\
\hline & $(0.009)$ & $(0.007)$ & $(0.008)$ & $(0.007)$ & $(0.008)$ & $(0.005)$ \\
\hline \multirow[t]{2}{*}{ Years of Schooling in US } & $0.081 * *$ & $0.075^{* *}$ & $0.074 * *$ & $0.075^{* *}$ & $0.075^{* *}$ & $0.068 * *$ \\
\hline & $(0.023)$ & $(0.025)$ & $(0.025)$ & $(0.025)$ & $(0.025)$ & $(0.023)$ \\
\hline \multirow[t]{2}{*}{ Years Since Migration (YSM) } & $0.090 * *$ & $0.091^{* *}$ & $0.091 * *$ & $0.092 * *$ & $0.092^{* *}$ & $0.072^{* *}$ \\
\hline & $(0.014)$ & $(0.014)$ & $(0.013)$ & $(0.014)$ & $(0.014)$ & $(0.009)$ \\
\hline \multirow[t]{2}{*}{ YSM squared (/100) } & $-0.249 * *$ & $-0.231 * *$ & $-0.235^{* *}$ & $-0.235^{* *}$ & $-0.235^{* *}$ & $-0.180 * *$ \\
\hline & $(0.051)$ & $(0.050)$ & $(0.050)$ & $(0.050)$ & $(0.050)$ & $(0.034)$ \\
\hline \multirow[t]{2}{*}{ Fertility in Source Country } & & $-0.083^{*}$ & -0.064 & -0.063 & -0.063 & -0.034 \\
\hline & & $(0.040)$ & $(0.048)$ & $(0.048)$ & $(0.048)$ & $(0.039)$ \\
\hline \multirow[t]{2}{*}{ Real GDP in Source Country (1995 \$US/1000) } & & 0.010 & 0.011 & 0.011 & 0.011 & $0.014^{*}$ \\
\hline & & $(0.007)$ & $(0.007)$ & $(0.007)$ & $(0.007)$ & $(0.005)$ \\
\hline \multirow{2}{*}{$\begin{array}{l}\text { Male Secondary Enrollment Rate in Source } \\
\text { Country }\end{array}$} & & -0.004 & -0.003 & -0.003 & -0.003 & -0.002 \\
\hline & & $(0.002)$ & $(0.002)$ & $(0.002)$ & $(0.002)$ & $(0.002)$ \\
\hline Male Primary Enrollment Rate in Source & & 0.002 & 0.002 & 0.002 & 0.002 & -0.000 \\
\hline Country & & $(0.002)$ & $(0.002)$ & $(0.002)$ & $(0.002)$ & $(0.001)$ \\
\hline \multirow{2}{*}{$\begin{array}{l}\text { Distance from Source Country to US } \\
\text { (miles/1000) }\end{array}$} & & 0.018 & 0.013 & 0.012 & 0.012 & 0.009 \\
\hline & & $(0.016)$ & $(0.016)$ & $(0.016)$ & $(0.016)$ & $(0.014)$ \\
\hline \multirow[t]{2}{*}{ English-Speaking Source Country } & & $0.417^{* *}$ & $0.382^{* *}$ & $0.380 * *$ & $0.380 * *$ & $0.218^{*}$ \\
\hline & & $(0.105)$ & $(0.123)$ & $(0.123)$ & $(0.123)$ & (0.097) \\
\hline \multirow[t]{2}{*}{ English-Official but not English-Speaking } & & $0.380 * *$ & $0.398^{* *}$ & $0.401^{* *}$ & $0.400 * *$ & $0.303^{* *}$ \\
\hline & & (0.104) & $(0.112)$ & $(0.112)$ & $(0.112)$ & $(0.071)$ \\
\hline \multirow[t]{2}{*}{ Female/Male Activity Ratio in Source Country } & & & 0.202 & 0.220 & 0.187 & 0.119 \\
\hline & & & $(0.247)$ & $(0.244)$ & $(0.263)$ & $(0.217)$ \\
\hline \multirow{2}{*}{$\begin{array}{l}\text { Interaction: Worked Before Migrating x } \\
\text { Female/Male Activity Ratio }\end{array}$} & & & & & 0.044 & 0.183 \\
\hline & & & & & $(0.174)$ & $(0.180)$ \\
\hline \multirow[t]{2}{*}{ Family Visa } & & & & & & -0.084 \\
\hline & & & & & & $(0.055)$ \\
\hline \multirow[t]{2}{*}{ Employment Visa } & & & & & & $0.516^{* *}$ \\
\hline & & & & & & (0.098) \\
\hline \multirow[t]{2}{*}{ Diversity Visa } & & & & & & $-0.165+$ \\
\hline & & & & & & $(0.082)$ \\
\hline \multirow[t]{2}{*}{ Refugee Visa } & & & & & & -0.106 \\
\hline & & & & & & $(0.076)$ \\
\hline \multirow[t]{2}{*}{ Legalization Visa } & & & & & & -0.115 \\
\hline & & & & & & $(0.100)$ \\
\hline $\mathrm{N}$ & 1533 & 1533 & 1533 & 1533 & 1533 & 1533 \\
\hline Adjusted R squared & 0.375 & 0.406 & 0.406 & 0.406 & 0.406 & 0.487 \\
\hline
\end{tabular}

$+p<0.10, * p<0.05, * * p<0.01$

Note: Sample includes those who migrated at age 18 or later and are no more than 65 years old. Standard errors are clustered at the source country level. Sample excludes those currently enrolled in school. Individuals with hourly earnings less than $\$ 1$ or greater than $\$ 250$ are excluded. Other controls include race/ethnicity, age and age squared. Omitted visa category is "other". Self-employed are excluded. 
Table A5: Selected OLS Regression Results, Annual Work Hours, Married Women

\begin{tabular}{|c|c|c|c|c|c|}
\hline & \multicolumn{4}{|c|}{ All Married Immigrant Women } & $\begin{array}{l}\text { Spouse from } \\
\text { Same Country }\end{array}$ \\
\hline & $(1)$ & $(2)$ & (3) & (4) & (5) \\
\hline Annual Work Hours Before Migrating & $\begin{array}{l}0.226 * * \\
(0.061)\end{array}$ & $\begin{array}{l}0.213^{* *} \\
(0.065)\end{array}$ & $\begin{array}{l}0.195^{* *} \\
(0.061)\end{array}$ & $\begin{array}{l}0.195 * * \\
(0.061)\end{array}$ & $\begin{array}{l}0.126+ \\
(0.071)\end{array}$ \\
\hline Female/Male Activity Ratio in Source Country & $\begin{array}{c}1089.217^{* *} \\
(289.545)\end{array}$ & $\begin{array}{l}978.268 * * \\
(266.435)\end{array}$ & $\begin{array}{l}933.060^{* *} \\
(229.604)\end{array}$ & $\begin{array}{l}933.413^{* *} \\
(228.758)\end{array}$ & $\begin{array}{l}929.280 * * \\
(233.331)\end{array}$ \\
\hline $\begin{array}{l}\text { Interaction: Annual Work Hours Before } \\
\text { Migrating x Female/Male Activity Ratio }\end{array}$ & $\begin{array}{l}-0.224^{*} \\
(0.089)\end{array}$ & $\begin{array}{l}-0.205^{*} \\
(0.094)\end{array}$ & $\begin{array}{l}-0.177+ \\
(0.089)\end{array}$ & $\begin{array}{l}-0.177+ \\
(0.089)\end{array}$ & $\begin{array}{l}-0.075 \\
(0.096)\end{array}$ \\
\hline Fertility in Source Country & $\begin{array}{c}43.811 \\
(34.420)\end{array}$ & $\begin{array}{c}46.949 \\
(37.330)\end{array}$ & $\begin{array}{c}64.557 \\
(39.639)\end{array}$ & $\begin{array}{c}64.712 \\
(39.258)\end{array}$ & $\begin{array}{c}79.659 \\
(57.162)\end{array}$ \\
\hline Real GDP in Source Country (\$US/1000) & $\begin{array}{l}-5.469 \\
(7.772)\end{array}$ & $\begin{array}{l}-3.098 \\
(6.911)\end{array}$ & $\begin{array}{l}-3.703 \\
(7.787)\end{array}$ & $\begin{array}{l}-3.699 \\
(7.765)\end{array}$ & $\begin{array}{c}2.794 \\
(9.234)\end{array}$ \\
\hline $\begin{array}{l}\text { Female Secondary Enrollment Rate in Source } \\
\text { Country }\end{array}$ & $\begin{array}{l}5.274^{* *} \\
(1.587)\end{array}$ & $\begin{array}{l}4.983^{* *} \\
(1.529)\end{array}$ & $\begin{array}{l}5.215^{* *} \\
(1.595)\end{array}$ & $\begin{array}{l}5.183^{* *} \\
(1.627)\end{array}$ & $\begin{array}{c}3.637 \\
(2.628)\end{array}$ \\
\hline $\begin{array}{l}\text { Female Primary Enrollment Rate in Source } \\
\text { Country }\end{array}$ & $\begin{array}{l}-2.854 \\
(2.622)\end{array}$ & $\begin{array}{l}-0.817 \\
(2.400)\end{array}$ & $\begin{array}{l}-0.731 \\
(2.451)\end{array}$ & $\begin{array}{l}-0.758 \\
(2.454)\end{array}$ & $\begin{array}{l}-1.715 \\
(3.015)\end{array}$ \\
\hline $\begin{array}{l}\text { Distance from Source Country to US } \\
\text { (miles/1000) }\end{array}$ & $\begin{array}{c}-67.058^{* *} \\
(21.603)\end{array}$ & $\begin{array}{l}-53.022^{*} \\
(22.872)\end{array}$ & $\begin{array}{l}-62.601^{*} \\
(23.080)\end{array}$ & $\begin{array}{l}-62.748^{*} \\
(22.957)\end{array}$ & $\begin{array}{l}-67.842 * * \\
(24.215)\end{array}$ \\
\hline English-Speaking Source Country & $\begin{array}{c}-8.069 \\
(189.826)\end{array}$ & $\begin{array}{c}42.562 \\
(171.626)\end{array}$ & $\begin{array}{c}5.515 \\
(173.835)\end{array}$ & $\begin{array}{c}1.191 \\
(170.811)\end{array}$ & $\begin{array}{l}-240.029 \\
(159.742)\end{array}$ \\
\hline $\begin{array}{l}\text { English-Official but not English-Speaking } \\
\text { Source Country }\end{array}$ & $\begin{array}{c}453.412^{* *} \\
(94.767)\end{array}$ & $\begin{array}{c}406.910^{* *} \\
(77.471)\end{array}$ & $\begin{array}{c}437.524^{* *} \\
(67.839)\end{array}$ & $\begin{array}{c}436.347^{* *} \\
(68.110)\end{array}$ & $\begin{array}{c}460.664^{* *} \\
(71.167)\end{array}$ \\
\hline Years of Schooling Before Migrating & $\begin{array}{l}11.973^{*} \\
(5.649)\end{array}$ & $\begin{array}{l}13.179 * \\
(5.829)\end{array}$ & $\begin{array}{c}2.072 \\
(6.911)\end{array}$ & $\begin{array}{c}2.001 \\
(6.890)\end{array}$ & $\begin{array}{l}-12.290 \\
(7.888)\end{array}$ \\
\hline Years Since Migration (YSM) & $\begin{array}{c}144.112^{* *} \\
(10.834)\end{array}$ & $\begin{array}{c}131.550^{* *} \\
(11.111)\end{array}$ & $\begin{array}{c}130.278^{* *} \\
(10.767)\end{array}$ & $\begin{array}{c}129.840 * * \\
(10.576)\end{array}$ & $\begin{array}{c}116.052^{* *} \\
(15.831)\end{array}$ \\
\hline YSM squared (/100) & $\begin{array}{c}-405.382^{* *} \\
(48.351)\end{array}$ & $\begin{array}{c}-361.893^{* *} \\
(48.670)\end{array}$ & $\begin{array}{c}-365.382^{* *} \\
(47.052)\end{array}$ & $\begin{array}{c}-364.048^{* *} \\
(46.740)\end{array}$ & $\begin{array}{c}-329.787^{* *} \\
(60.084)\end{array}$ \\
\hline Number of Own Children Ever Born & & & $\begin{array}{c}-69.105^{* *} \\
(17.617)\end{array}$ & $\begin{array}{c}-68.937^{* *} \\
(17.758)\end{array}$ & $\begin{array}{c}-74.270 * * \\
(21.938)\end{array}$ \\
\hline
\end{tabular}


Table A5: Selected OLS Regression Results, Annual Work Hours, Married Women (ctd)

\begin{tabular}{|c|c|c|c|c|c|}
\hline & \multicolumn{4}{|c|}{ All Married Immigrant Women } & \multirow{2}{*}{$\begin{array}{l}\text { Spouse from } \\
\text { Same Country } \\
\text { (5) }\end{array}$} \\
\hline & (1) & $(2)$ & (3) & (4) & \\
\hline \multicolumn{6}{|l|}{ Spouse Variables: } \\
\hline \multirow[t]{2}{*}{ Hispanic } & & & -68.760 & -67.727 & -18.601 \\
\hline & & & $(70.255)$ & (70.329) & $(56.674)$ \\
\hline \multirow[t]{2}{*}{ Asian } & & & -7.451 & -5.969 & -75.205 \\
\hline & & & $(100.522)$ & (101.995) & (111.199) \\
\hline \multirow[t]{2}{*}{ Black Nonhispanic } & & & -100.607 & -100.391 & -87.551 \\
\hline & & & $(62.526)$ & $(62.730)$ & (113.914) \\
\hline \multirow[t]{2}{*}{ Other race } & & & 192.182 & 195.162 & 351.453 \\
\hline & & & $(267.685)$ & $(268.673)$ & (316.149) \\
\hline \multirow[t]{2}{*}{ Age } & & & -33.439 & -33.003 & -35.779 \\
\hline & & & $(25.893)$ & $(26.047)$ & $(42.870)$ \\
\hline \multirow[t]{2}{*}{ Age Squared } & & & 0.472 & 0.466 & 0.499 \\
\hline & & & (0.321) & $(0.323)$ & $(0.517)$ \\
\hline \multirow[t]{2}{*}{ Years of Schooling Before Migrating } & & & -0.440 & -0.434 & 11.007 \\
\hline & & & (8.269) & (8.265) & (10.079) \\
\hline \multirow[t]{2}{*}{ Years of Schooling in US } & & & 6.094 & 5.945 & 23.165 \\
\hline & & & (11.103) & (11.283) & $(13.926)$ \\
\hline \multirow[t]{2}{*}{ Immigrant } & & & -5.284 & 22.328 & \\
\hline & & & $(92.658)$ & (121.178) & \\
\hline \multirow[t]{2}{*}{ Born in Wife's Birth Country } & & & & -34.483 & \\
\hline & & & & (127.169) & \\
\hline Own Visa Categories in Regession? & no & yes & yes & yes & yes \\
\hline N & 1782 & 1782 & 1782 & 1782 & 1480 \\
\hline r squared & 0.192 & 0.198 & 0.207 & 0.207 & 0.197 \\
\hline
\end{tabular}

$+p<0.10, * p<0.05, * * p<0.01$

Regressions also control for own age, age squared, and race/ethnicity dummies. 